



\section{Integration genom vuxenutbilding och fortbilding}

Landrapport Finland

Petri Salo och Pia-Stina Sarin

TemaNord 2010:562 


\section{Integration genom vuxenutbilding och fortbilding}

Landrapport Finland

TemaNord 2010:562

(C) Nordiska ministerrådet, Köpenhamn 2010

ISBN 978-92-893-2092-4

Publikationen är tillgänglig som Print on Demand (PoD) och kan beställas på www.norden.org/order.

Fler publikationer finns på www.norden.org/publikationer.

\section{Nordiska ministerrådet}

Ved Stranden 18

DK-1061 Köpenhamn K

Telefon (+45) 33960200

Fax (+45) 33960202

\author{
Nordiska rådet \\ Ved Stranden 18 \\ DK-1061 Köpenhamn K \\ Telefon $(+45) 33960400$ \\ Fax (+45) 33111870
}

www.norden.org

\section{Det nordiska samarbetet}

Det nordiska samarbetet är ett av världens mest omfattande regionala samarbeten. Det omfattar Danmark, Finland, Island, Norge och Sverige samt de självstyrande områdena Färöarna, Grönland och Åland.

Det nordiska samarbetet är politiskt, ekonomiskt och kulturellt förankrat och är en viktig partner i europeiskt och internationellt samarbete. Den nordiska gemenskapen arbetar för ett starkt Norden i ett starkt Europa.

Det nordiska samarbetet vill styrka nordiska och regionala intressen och värderingar i en global omvärld. Gemensamma värderingar länderna emellan bidrar till att stärka Nordens ställning som en av världens mest innovativa och konkurrenskraftiga regioner. 


\section{Innehåll}

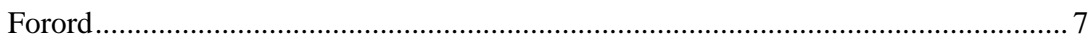

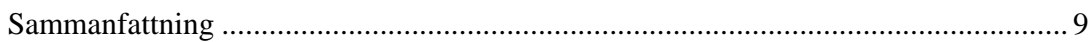

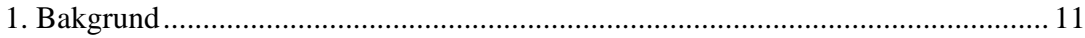

2. Nationella strategier inom ramen för det finländska vuxenutbildningssystemet ....................................................................................... 13

2.1 Lagstiftning och nationella policyn beträffande vuxenutbildning för invandrare.............................................................. 13

2.2 Centrala aktörer........................................................................................... 21

2.3 Nationella aspekter.................................................................................... 24

3. Initiativ till att förstärka integrationen genom vuxenutbildning .............................. 27

3.1 Systemet för integration och utbildning för vuxna invandrare. …………….... 28

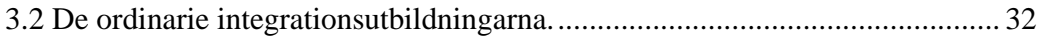

4. Särskilda satsningar för att utveckla den integrationsfrämjande

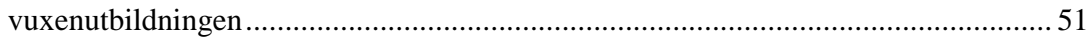

4.1 EU-finansierad integrationsfrämjande projektverksamhet ............................... 51

4.2 Kultur- och språkutbildning. …………………………………………….... 58

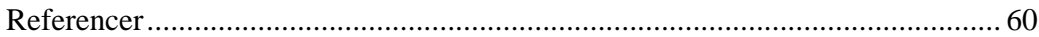





\section{Forord}

Nationalt Center for Kompetenceudvikling har foretaget en komparativ undersøgelse af integration af indvandrere og efterkommere gennem voksen- og efteruddannelse i de nordiske lande.

Resultaterne af undersøgelsen fremlægges i fem nationale rapporter og en rapport med tværgående analyser og sammenfatninger. Denne rapport beskriver de finske resultater. Alle rapporterne kan findes på www.ncfk.dk under publikationer.

Undersøgelsen er gennemført af Nationalt Center for Kompetenceudvikling i samarbejde med Islands Universitet, Institut for fremmedsprog, litteratur og lingvistik, Norges Teknisk-Naturvidenskabelige Universitet, Forskningsenheden voksne i livslang læring, Gøteborgs Universitet, og Åbo Akademi i Vasa, Det pædagogiske fakultet.

Undersøgelsen er gennemført på opdrag af og med økonomisk støtte fra Nordisk Ministerråd.

Undersøgelsen er den første samlede tværnordiske kortlægning af området. Det er vor opfattelse, at samspillet mellem integration og voksenuddannelse er både aktuelt relevant og politisk vigtigt. Det er vort håb, at det fremlagte materiale vil kunne bidrage til nordisk inspiration og handling for såvel uddannelsesadministratorer, forskere som praktikere.

Bjarne Wahlgren,

Centerleder, januar 2010 



\section{Sammanfattning}

Den finländska integrationspolitiken har under 2000-talet kommit att allt starkare präglas av arbetsmarknadsorientering och arbetslivsanknytning. Ansvaret för utbildning av vuxna invandrare är fördelat mellan Arbets- och näringslivsministeriet och Undervisningsministeriet, det förstnämnda svarar för finansieringen och formen, det senare nämnda för innehållet i ett nationellt perspektiv. Villkoren för och genomförandet av utbildningarna varierar kraftigt mellan regioner och orter, inte minst på grund av att t.ex. de arbetskraftspolitiska integrationsutbildningarna kan genomföras av diverse aktörer, såväl av vuxenutbildningscenter (med profilering mot arbetskraftspolitisk vuxenutbildning) som av t.ex. folkhögskolor (med profilering mot folkbildning). Det finns inga uppföljningar eller utvärderingar av hur de nationella läroplanerna för integrationsutbildningarna, som aktiv uppdaterats de senaste åren, förverkligas av olika organisatörer. Överhuvudtaget är möjligheterna att få en samlad överblick begränsade. Detta på grund av att övergripande nationell statistik i vilken invandrare skulle uppmärksammas som en särskild grupp saknas. Det övergripande syftet, att integrera utbildning av vuxna invandrare allt starkare i den ordinarie vuxenutbildningen kan i princip ha två motsatta utfall. En invandrare med goda förutsättningar (t.ex. tidigare utbildning, grundläggande språkkunskaper) kan med hjälp av god vägledning finna en meningsfull utbildningsväg och genom att delta i ordinarie vuxenutbildning bli integrerad i ordets egentliga betydelse. Men för en invandrare med sämre förutsättningar och bristfällig tillgång till vägledning, rådgivning och information är risken för marginalisering uppenbar. 



\section{Bakgrund}

Fram till början 1980-talet var invandringen till Finland mycket blygsam, antalet invandrare var drygt 10000 personer. Under 1980-talet fyrdubblades antalet till 50000 personer, dvs. 0,9\% av befolkningen. Efter Sovjetunionens sönderfall började invandringen fr.o.m. 1990-talets början öka. De två största invandrargrupperna har kommit att bli ryssar (19 \% av invandrarna) och estländare (16 \% av invandrarna). Orsaken till det stora antalet invandrare från Ryssland är att ingermanländare med rötter i Finland fick en återflyttarstatus. De därefter största grupperna är svenskar (varav majoriteten återflyttare) och somalier (4900 personer). Det totala antalet invandrare var år 2008 cirka 143000 personer, 2,5 \% av befolkningen. Invandrarna är geografiskt mycket ojämnt fördelade, de bor idag främst i stora städer, i Nyland och huvudstadsregionen där andelen är 4,4 \% av befolkningen (omkring hälften av alla invandrare). De första flyktingarna anlände i början av 1970-talet från Chile. Först 1986 förband sig Finland att ta emot kvotflyktingar, idag är den årliga flyktingkvoten 750 personer. Antalet flyktingar var i slutet av år 2006 cirka 28 000 (23 \% av invandrarna), som under sin tid i Finland har fått drygt 5000 barn. Även antalet asylsökanden har varit mycket liten, t.ex. år 2006 omkring 1500 personer. Den huvudsakliga orsaken till invandringen till Finland har varit familjeband. På senare tid har den arbetsrelaterade invandringen ökat. Eftersom befolkningen åldras och efterfrågan på arbetskraft ökar är målet att den arbetsrelaterade invandringen till Finland skall öka från såväl EU-området som länder utanför den (Arajärvi 2009, 6-21; Sisäasianministeriö 2008, 6-9).

Av invandrarna är 79 \% i arbetsför ålder (15-64 år), vilket är en relativt hög siffra jämfört med befolkningen i sin helhet (66 \%). Arbetslösheten bland invandrarna har sjunkit under 1990- och 2000-talen, särskilt 2004 framåt. År 1994 var nästan hälften av invandrarna arbetslösa, år 2000 var andelen arbetslösa knappt en tredjedel och år 2008 något över en femtedel. Arbetslösheten bland invandrare är tre gånger så stor som hos finländarna i allmänhet. In- 
vandrarkvinnornas arbetslöshet (25,2 \%) var år 2007 klart större än männens (15,8 \%). Arbetslösheten är särskilt hög bland somaliska, irakiska, iranska, afganistanska och marokanska medborgare (Ibid.).

Tabell 1. Antal invandrare i arbetsför ålder, antal arbetslösa och arbetslöshetsprocenten (Inrikesministeriet 2008, 7)

\begin{tabular}{lrrrrr}
\hline & $\mathbf{2 0 0 4}$ & $\mathbf{2 0 0 5}$ & $\mathbf{2 0 0 6}$ & $\mathbf{2 0 0 7}$ & $\mathbf{2 0 0 8}$ \\
\hline Invandrare i arbetsför ålder & 83498 & 88745 & 95851 & 104170 & 113000 \\
Antal arbetslösa & 15051 & 15054 & 14460 & 13970 & 13152 \\
Arbetslöshet i procent & $29,30 \%$ & $27,50 \%$ & $24,30 \%$ & $21,60 \%$ & $21,50 \%$ \\
\hline
\end{tabular}

Invandrarnas arbetsförmåga har konstaterats vara bra. I en undersökning (Holm, Hopponen \& Lahtinen 2008) uppskattade 87 \% av invandrarna sin arbetsförmåga vara god eller utmärk. Majoriteten av invandrarna var villiga att delta i arbetslivet, $90 \%$ av dem var aktiva arbetssökande. De flesta invandrare är sysselsatta inom jord- och skogsbruk och industri. Den minsta andelen utländsk arbetskraft finns inom offentlig service och handel. Den befintliga men bristfälliga statistiken visar att invandrarna, flyktingarna som undantag, är relativt välutbildade. Omkring en tredjedel av invandrarna har grundläggande utbildning, likaså omkring en tredjedel utbildning på andra stadiet och drygt en femtedel högre utbildning (Sisäasiainministeriö 2008, 9). 


\section{Nationella strategier inom ramen för det finländska vuxenutbildningssystemet}

I det följande redovisas för innehållet i de mest centrala invandrar- och utbildningspolitiska policy-dokumenten under det senaste årtiondet. Man kan notera att integrationen har främst hanterats (fram till 2007) inom Undervisningsministeriets förvaltningsområde, med en allt starkare betoning på yrkesutbildning, arbetsmarknadsrelevans och validering. År 2007 framåt flyttas tyngdpunkten till arbetsrelaterad invandring, och integration har kommit att hanteras i samverkan mellan flera ministerier. Den tyngdpunkförskjutning från utbildning till vägledning, som gäller för finländsk vuxenutbildning överlag, framkommer även i fråga om integration genom vuxenutbildning.

\subsection{Lagstiftning och nationella policyn beträffande vuxenutbildning för invandrare}

Den finländska invandrarpolitiken granskades för första gången i sin helhet år 1997 genom ett flykting- och invandrarpolitiskt program. Målet var att invandrare skulle integreras i det finländska samhället och arbetslivet på ett smidigt och effektivt sätt. Med integrering syftade man till att invandrarna deltar som samhällets fullvärdiga medlemmar i det ekonomiska, politiska och sociala livet. Utgångspunkten för programmet var att såväl samhället och invandrarna gagnas av att invandrarna bereds möjlighet att bevara sitt modersmål och värna sin ursprungliga kultur. Denna målformulering och definition på integrering har utgjort plattformen för invandrarpolitiken under 2000- 
talets början, och refereras till i så gott som samtliga policy -dokument (Statsrådet, 2008, 4; Opetusministeriö 2002, 92).

Programmet resulterade i en integreringslag år 1999, det första i sitt slag i Europa. I den tog man fasta på mottagandet av flyktingar och allmänna åtgärder för integrationsfrämjandet. Tyngdpunkten låg på humanitär invandring. (Statsrådet, 2008, 4). Det huvudsakliga innehållet i lagen (280/2006) har varit oförändrad från år 1999 till år 2006. I 1 § har syfte utvidgats att omfatta personer som behöver skydd på grund av massflykt eller är offer för människohandel. I 2 § har det skett en precisering, nämligen att planeringen och anordnandet av tjänster och åtgärder skall utgå från invandrares behov.

- $1 \S$ Syftet med denna lag är att främja invandrares integration, jämlikhet och valfrihet genom åtgärder som stöder förvärvande av sådana centrala kunskaper och färdigheter som behövs i samhället samt att genom arrangemang för mottagande trygga försörjning för och omsorg om asylsökande och personer som får tillfälligt skydd på grund av massflykt. Syftet med denna lag är dessutom att hjälpa offer för människohandel.

- 2 § I denna lag avses med 1) integration invandrarens individuella utveckling med målet att delta i arbetslivet och samhällslivet och samtidigt bevara sitt språk och sin kultur, 2) integrationsfrämjande av myndigheterna ordnade åtgärder, resurser och tjänster för främjande och stödjande av integration samt beaktande av invandrares behov vid planering och anordnande av andra tjänster och åtgärder i samhället.

Inga specifika målformuleringar ingår lagen. Den består främst av en beskrivning av olika myndigheters uppgifter vid integrering. Utbildning som integreringsinstru-ment är framträdande, de fem första åtgärderna är relaterade till utbildning.

- 7 § Åtgärder och tjänster som främjar och stöder integration. Arbetskraftsbyrån och kommunen kan som åtgärder och tjänster som främjar och stöder integration ordna 1) vägledning, rådgivning och information, 2) introduktion i samhället och samhällslivet, 3) undervisning i finska och svenska, 4) åtgärder jämställbara med arbetskraftspolitisk vuxenutbildning och arbetskraftsåtgärder, 5) undervisning i läs- och skrivkunnighet samt undervisning som 
kompletterar den grundläggande utbildningen, 6) tolkning, 7) åtgärder och tjänster som främjar jämlikhet och likställdhet, 8) åtgärder och tjänster som påkallas av specialbehov bland minderåriga, 9) åtgärder och tjänster för grupper som behöver särskilt stöd 10) andra åtgärder och tjänster som stöder invandrare att på egen hand skaffa sig de kunskaper och färdigheter som behövs i samhället.

Lagformuleringarna sammanföll med principer och riktlinjer inom den

Europeiska unionen. Integrationsfrämjandet skulle vara dubbelriktat; handla både om invandrarnas strävan efter att bli integrerade och samhällets strävan efter att anpassa sig till den nya situationen. I lagen ersattes låneordet "integraatio" (integration) med "kotoutuminen" (att bli hemmastadd) och "integrationsfrämjande” med "kotouttaminen" (att främja den process genom vilken någon blir hemmastadd. (Statsrådet, 2008, 15)

Under 2000-talet har invandring p.g.a. familjeband arbete har ökat medan den humanitära invandringen har minskat. I Regeringsprogrammet (2007) definieras målet för invandrarpolitiken enligt följande "att utveckla en aktiv, övergripande och konsekvent politik som fullt ut beaktar såväl behovet av arbetskraft som invandrarnas varierande utgångspunkter och de internationella förpliktelserna.” (s. 24). Fokusen ligger på den arbetsrelaterade invandringen. Åtgärderna handlar om att öka öppenheten och förbättra förutsägbarheten i myndigheternas verksamhet. Systemet med uppehållstillstånd skall förtydligas, omfatta såväl rätt att arbeta och studera. Asylsökanden som fått avslag på sin asylansökan men hunnit få en arbetsplats skall ha möjlighet att ansöka om uppehålls- och arbetstillstånd, förutsatt att kriterierna för att stanna i Finland som arbetstagare uppfylls. Utbildningens funktion beskrivs i ytterst allmänna ordalag. Behovet av ökad språkutbildning och av ett nytt vägledningssystem för arbetskraftsinvandrare understryks. Det fria bildningsarbetet (folkbildningen) tilldelas en uppgift i att utveckla utbildningsmöjligheter för invandrare och vuxna som riskerar marginalisering (s. 33).

I övrigt hänvisar man till Regeringens invandrarpolitiska program (Hallituksen maahanmuuttopoliittinen ohjelma 2006), ett strategidokument i vilket det övergripande målet definieras på följande sätt; "definiera invandringspolitikens värden och respektera de mänskliga rättigheterna och de grundläggande fri- och rättigheterna, verka för en god förvaltningskultur samt avvärja hot i samband med invandring." (s.2) Programmets skall fungera som ett ram för planering och verkställighet av invandrarpolitiken. Fokusen ligger särskilt på 
invandring från utanför EU och EES -området. Programmet har tre syften: ”a) främja utvecklingen mot ett pluralistiskt, mångkulturellt och ickediskriminerande samhälle och på så sätt stödja internationaliseringen i Finland, b) förbättra den internationella konkurrenskraften och c) som ett medel bland andra svara mot de utmaningar som den åldrande arbetskraften och befolkningen medför." Åtgärderna handlar om att främja arbetsrelaterad invandring samt studerande- och forskarinvandring.

Utbildning som integreringsinstrument behandlas i anslutning till utbildning i invandrarföretagande och i samband med validering och erkännande av invandrarnas tidigare utbildning. Fokusen ligger på vägledning som ett medel för att invandrarna skall kunna dra nytta av det ordinarie vuxenutbildningssystemet. Man noterar att vuxna invandrare utanför arbetskraften, särskilt kvinnor och de som saknar läs- och skrivfärdigheter, deltar i integrationsutbildningen endast slumpmässigt. Integrationsutbildningen utvecklas så att den utgör en del av ett kontinuum för fortsatta studier och svarar mot individuella utbildningsbehov. Detta förutsätter tydligare ansvarsfördelning mellan utbildnings- och arbetskraftsmyndigheter. Beträffande den till yrkesutbildning förberedande utbildningen noterar man att informationen om den bör utvecklas, att den utvidgas till att omfatta ett läsår och att lärarnas mångkulturella kompetens höjs. I övrigt handlar åtgärdsförslagen om att underlätta invandrarnas möjligheter att delta i och minska avbrott inom den ordinarie yrkesutbildningen. Medlen är ökad tydlighet i antagningsförfaranden, förbättrade stödformer samt ökad arbetslivspraktik (s. 22-25). I programmet betraktas invandringen i ett helhetsperspektiv. Tyngdpunkten ligger i arbetsrelaterad invandring, effektivisering av styrningen och främjandet av de etniska relationerna mellan olika befolkningsgrupper. Effektiv vägledning för orientering i det finländska samhället poängteras, likaså dubbelriktningen och behovet av att beakta invandringen inom samtliga samhällssektorer.

\section{Undervisningsministeriet}

Fram till år 2007 hanterades vuxenutbildning för invandrare främst inom ramen för Undervisningsministeriets verksamhetsområde och utvecklandet av vuxenutbildningssystemet som helhet. Den parlamentariska arbetsgruppen för vuxenutbildning (Opetusministeriö 2002) såg på vuxenutbildningens funktion i sin helhet. I sin promemoria definierar gruppen vuxenutbildningens funktion vara att stärka deltagande demokrati, stöda aktivt medborgarskap och förhindra marginalisering. Invandrare betraktas, i likhet med handikappade 
och arbetslösa som en specialgrupp, vars utbildningsmöjligheter bör förbättras. Invandrare tas upp i anslutning till att man uppmärksammar behovet att höja yrkeskompetensen och utbildningsnivån hos de vuxna som saknar utbildning efter grundläggande utbildning (s. 16). Man fokuserar behovet av baskunskaper i språk samt validering och uppgradering av tidigare kunskaper och färdigheter. I övrigt tar man målgruppsvis (arbetslösa invandrare, invandrare som saknar läs- och skrivfärdigheter, unga invandrare som överstigit läropliktsåldern, högt utbildade invandrare) endast fasta på det framtida utbildningsbehovet i form av studieplatser.

I Undervisningsministeriets invandrarpolitiska linjedragningar (Opetusministeriö 2003) noteras att den ökade invandringen skall hanteras inom det allmänna utbildningssystemet. Definitionen på invandrare omfattar alla som bor stadigvarande i Finland men är inte finska medborgare. Dessa skall ha samma möjligheter som finländare i fråga om att dra nytta av utbildningstjänster och studiesociala förmåner. Målet är att vuxna invandrare skall kunna delta i integrationsutbildning omedelbart efter invandringen, vid behov i grundläggande yrkesutbildning och fortbildning. Åtgärderna för validering och erkännande av invandrarnas tidigare utbildning skall effektiveras

Vuxna invandrare skall garanteras möjlighet till yrkesutbildning och upprätthållande yrkeskompetensen. För yrkesutbildningens del noterar man att läroplansgrunderna innehåller särskilda avsnitt med rekommendationer om hur invandrarstuderandes behov skall beaktas. Yrkesläroanstalterna uppmanas att utveckla sina planer för organisering av undervisningen för invandrare. De förväntas vidta stödåtgärder för att kunna försäkra sig om invandrarnas språkfärdigheter vid antagning och på så sätt förebygga studieavbrott. Samarbetet läroanstalterna emellan betonas. Arbetsgivare uppmanas att öka antalet invandrare som skaffar sig yrkesutbildning genom läroavtal. Högskolorna förväntas anta flera utländska studerande, utveckla studier på främmande språk och uppgöra individuella studieplaner för utländska studerande. De för integrationsutbildningen specifika åtgärderna handlar om ansvarsfördelning och resursering. Arbetsministeriet behåller sitt ansvar för utbildning av arbetslösa invandrare. Ansvaret för utbildning av icke-läs- och skrivkunniga flyktingar och invandrare överförs till Undervisningsministeriet.

Utvecklingsprogrammet för gymnasieutbildningen för vuxna (Opetusministeriö 2006a) omfattar åtgärderna vid sidan om språkfärdigheter större uppmärksamhet på inlärningssvårigheter och studievägledning. Man tar fasta på lärarnas grundutbildning och behovet av ett ökat samarbete myndigheterna 
emellan. Arbetsgruppen föreslår en utredning om möjligheten att kostnadseffektivt sammanföra integrationsutbildningen i det allmänna utbildningssystemet. Avslutningsvis föreslår arbetsgruppen en studiehelhet i gymnasiets läroplan som skulle omfatta innehållet i den grundläggande undervisningen (åk. 1-6) och rikta sig särskilt mot invandrare utan läs- och skrivfärdigheter och som saknar grundläggande utbildning.

I Statsrådets utbildningspolitiska redogörelse till riksdagen (Valtioneuvoston koulutuspoliittinen selonteko eduskunnalle 2006) noteras att utvecklingen av utbildningssystemet präglats av mål och åtgärder med syfte att stöda samhälls- och sysselsättningspolitiken. Ansvaret för utbildning av invandrare konstateras omfatta samtliga nivåer och sektorer av utbildningssystemet. Det utvecklingsarbetet genom vilket man strävat efter att beakta invandrarnas specialbehov bör fortsätta. Man betonar språkundervisningen och studiehelheter som syftar till att orientera invandrare i det finländska samhället och kulturen. I undervisning i språk- och kultur tilldelas det fria bildningsarbetet (folkbildningen) en särskild uppgift. Ytterligare tar man fasta på lärarfortbildning i mångkulturalitet.

I Undervisningsministeriets (2003) utvecklingsplan Utbildning och forskning 2003-2008 tar man fasta på invandrarutbildningen, främst på barn- och ungdomsstuderanden. I det därpå följande fyraårsplanet Utbildning och forskning 2007 - 2012 (Undervisningsministeriet 2007) konstaterar man (s. 12) att då tillgången på kunnig arbetskraft minskar gäller det att se till att invandrarnas begåvningsresurs används fullt ut. Tyngdpunkten i vuxenutbildning, också för invandrarnas del, är i yrkesutbildning och särskilt yrkesutbildningens arbetslivsmotsvarighet. Den framtida arbetskraftsbristen förutsätter stödjandet av arbetsrelaterad invandring och invandrarnas sysselsättning. Man tar särskilt fasta på utbildningsarrangemang med hjälp av vilka man avser utbilda invandrare inom givna branscher (bygg-, metall- och servicebranschen, hälso- sjukvård och äldreomsorg). Även validering, erkännande av examen och språkutbildning för invandrare utanför arbetsmarknaden, särskilt mödrar i invandrarfamiljer, tas upp. Det fria bildningsarbetet tilldelas en uppgift i förebyggandet av marginalisering och främjandet av invandrarnas språk- och kulturfärdigheter samt integration i samhället. Men även det fria bildningsarbetet skall ge invandrarna "möjligheter att förvärva kunnande som behövs i arbetslivet och som ger behörighet för fortsatta studier " (s. 53).

Under åren 2005-2007 genomförde läroanstalterna inom det fria bildningsarbetet, med särskilda projektmedel från Utbildningsstyrelsen, så kallade 
riktlinjestudier. Ett av tyngdpunktsområden var språk- och kulturfärdigheter samt i samhället integrerande studier för invandrare. Samtliga läroanstaltsformer engagerade sig i riktlinjerstudier i för invandrare. Nästan hälften (42 \%) av projekten inriktade mot invandrare. Utfallet av denna projektverksamhet var att man kom att utveckla, ofta i samverkan med andra läroanstalter eller myndigheter på lokalt och regionalt plan, arbetsformer för på ett mera långsiktigt och systematiskt sätt rekrytera, planera och genomföra språk- och annan undervisning utgående från de särskilda förutsättningar och behov som invandrare har (Vaherva m. fl. 2007).

\section{Undervisningsministeriet, Arbets- och näringsministeriet och} Inrikesministeriet

Efter att det operativa ansvaret för invandrarutbildningen länge hanterats inom Undervisningsministeriets förvaltningsområde ändras situationen mot slutet av 2000-talet. Målet med Arbetsplats 2008-2012. Ett vuxenutbildningsprogram för främjande av arbetsrelaterad invandring och sysselsättning av invandrarbefolkningen (Opetusministeriö ja Työministeriö 2007) är att stöda den arbetsrelaterade invandringen. Det sammanställdes i samarbete med Undervisningsministeriet och Arbetsministeriet. Programmet är en del av förnyelsen av den yrkesinriktade vuxenutbildningen. Vuxenutbildning betraktas allt tydligare som medel för att stöda aktiv invandringspolitik med fokus på arbets-relaterad invandring. Man understryker behovet av ett intensifierat samarbete och koordinering mellan myndigheter, kommuner, arbetsgivare, vuxenutbildnings-organisationer, universitet och högskolor samt invandrarorganisationer. Programmet innefattar särskilda vuxenutbildningsåtgärder för att främja sysselsättningen bland invandrarna. För ändamålet krävs dock tilläggsresurser samt åtgärder för att skräddarsy tjänsterna. Utbildning och vägledning/rådgivning skall fungera som en integrerad helhet. Man menar att indelningen av behov av vägledningstjänster eller vuxenutbildning enligt orsak till invandring konstgjord. Utbildningsbehoven ses som en helhet. Invandrarna skall kunna dra nytta av de existerande utbildnings- och vägledningssystemet. Man bör dock kunna svara mot de alltmer individualiserade behoven av information, vägledning och utbildning. Individualiseringen gäller även för validering, och erkännande av examen, undervisning i språk, kartläggning av yrkesmässig orientering och yrkesmässig fortbildning.

Arbets- och näringslivsministeriets verksamhetsplan för invandrarärenden (2008) har som mål att främja arbetsrelaterad invandring, underlätta erhållan- 
det av uppehållstillstånd, effektivera verkställandet av integreringen (integrationsplaner, integrationsutbildning, validering), främja sysselsättningen och företagandet bland invandrarna.

År 2008 utvidgas hanteringen av vuxenutbildning med integrerande och sysselsättningsfrämjande syften ytterligare. Vuxenutbildningens uppgifter för främjande av sysselsättningen av invandrare. (Sisäasiainministeriö 2008) sammanställdes av en tjänstemannagrupp från Undervisningsministeriet, Arbets- och Näringsministeriet, Inrikesministeriet samt Social- och hälsovårdsministeriet. Fokusen ligger på arrangemang som stöder en invandring som svarar mot framtida arbetskraftsbehov, särskilt inom sektorer som lider av framtida arbetskraftsbrist. Man tar särskilt fasta på validering och språkundervisning, utvecklandet och utvidgandet utbildningsmodeller och läroavtalsutbildning som lämpar sig för invandrare. Vidare fokuseras åtgärder som främjar de högtutbildade invandrarnas möjligheter att placera sig på arbetsmarknaden samt utbildningstjänster för arbetsgivare, särskilt inom små och medelstora företag, med behov av att anställa invandrare. För detta behövs utbildning av arbetsplatshandledare som behärskar invandrarnas språk och arrangemang för introduktion av nyanställda invandrare

Åtgärdsförslagen indelas tre övergripande områden. Vägledning och rådgivning omfattar nya verksamhetsmodeller, regional koordinering av tjänster för invandrare, sänkta trösklar för att dra nytta av de existerande tjänsterna, produktion av guider och informationsmaterial samt sammanställning och koordinering av modeller för validering, särskilt kartläggning av realkompetenser. Integrationsutbildningen skall anpassas enligt målgrupp (orsak till invandring), och dess arbetslivsanknytning och -relevans stärkas. Undervisningen för icke-läs- och skrivkunniga avses bli koordinerad med allmänbildande grundundervisning. Mödrar i stora familjer skall beredas möjligheter att delta i språkundervisning för. De ekonomiska möjligheterna till att delta i jämförbar utbildning utvecklas. Bättre regional koordinering av och ansvarsfördelning för undervisning i finska och svenska understryks, likaså betydelsen av informationsmaterial om vägledningstjänster och möjligheter till språkstudier. Utvecklandet av det yrkesmässiga kunnandet skall främjas genom målgruppsanpassade och skräddarsydda lösningar för rådgivning och utbildning. Detta gäller för läroavtalsutbildning, fristående examen och företagande. Vid behov, om underlag finns, skall man erbjuda invandrare möjlighet att studera i egna grupper inom yrkesutbildningen. Invandrarna, även de 
som inte berörs av integrationslagen, skall ges större möjligheter att delta jämförbar utbildning, särskilt inom social- och hälsovårdssektorn.

\section{Sammanfattning}

Det som kännetecknar integration genom vuxenutbildning är en allt starkare strävan efter att integrera den i den ordinarie (vuxen)utbildningen. Inom ramen för vuxenutbildning (även för invandrare) har fokusen flyttats från utvecklandet av yrkeskompetenser genom utbildning till direkt arbetsmarknadsrelevans, dvs. att ersätta eller komplettera studier med praktik och lärande-iarbete. Ett annat kännetecken är individualisering, som bygger dels på kartläggning, validering och erkännande av tidigare kompetenser och examen, dels på vägledning och rådgivning för att kunna möjliggöra individualiserad och skräddarsydda lösningar. Här skiljer sig dock inte vuxenutbildning för integration från de gällande trenderna inom vuxenutbildningen överlag. Trots att integration i det finländska samhället och kulturen är ett av de övergripande målen för integrationspolitiken, noteras varken undervisningen i finska/svenska eller integrering i samhället och kulturen på ett särskilt framträdande sätt. I fråga om integration i kulturen tilldelas det fria bildningsarbetet (folkbildningsorganisationerna) en särskild uppgift.

\subsection{Centrala aktörer}

Integrationen hanteras nästan uteslutande inom tre ministeriers ansvarsområde. De är Inrikesministeriet, Arbets- och näringsministeriet och Undervisningsministeriet.

Statsrådet (Regeringen) styr migrationspolitiken och -förvaltningen utgående från de mål som fastställts i regeringsprogrammet och de principer som statsrådet har godkänt. Sedan år 2008 har Inrikesministeriet det övergripande ansvaret för Finlands invandrarpolitik och -förvaltning (TEM, 2008, 2). Ministeriet ansvarar för utvecklingen, planeringen, styrningen, uppföljningen och samordningen av integrationsfrämjandet och mottagandet av asylsökande och mottagandet av personer som får tillfälligt skydd samt verkställigheten av hjälp till offer för människohandel. (L 972/2007). I anslutning till Inrikesministeriet finns en delegation för integrationsfrämjande och mottagande av asylsökande. Statsrådet tillsätter delegationen för tre år i sänder. (F 280/2006). Migrationsverket, 
som innan år 2008 benämndes Utlänningsverket, lyder under Inrikesministeriet och är Finlands centrala immigrationsmyndighet och behandlar och avgör ärenden som gäller utlänningars inresa och vistelse i landet, ansökningar om uppehållstillstånd och asyl, flyktingstatus samt frågor som gäller finskt medborgarskap (www.migri.fi)

Länsstyrelsen vid de fem länen deltar i planeringen, styrningen och övervakningen av åtgärder och tjänster som främjar och stöder integrationen av invandrare i ärenden som ingår dess verksamhetsområde. Länsstyrelsen ser till att invandrarnas behov beaktas vid planeringen och anordnandet av sådana tjänster och åtgärder som hör till dess verksamhetsområde. (L 1215/2005).

Kommunerna är ansvariga för att utarbeta ett program för integrationsfrämjande, som skall omfatta främjande av etnisk jämlikhet och goda etniska relationer och förebyggande av diskriminering. Kommunen är ansvarig för att programmet verkställs och utvecklas, likaså att dess genomförande och verkningar följs upp. Kommunen skall även ta initiativ till att Arbets- och näringsbyrån samt andra myndigheter deltar i utarbetandet och verkställandet av programmet i fråga om sitt eget verksamhetsområde. Kommunen är ansvarig för att utarbeta integrationsplaner för sådana invandrare som inte är skyldiga att anmäla sig som arbetssökande, behöver kommunens socialservice. Kommunen är allmänt ansvarig och samord-ningsansvarig över integrationsfrämjande åtgärder och tjänster på lokal nivå som inte är arbetskraftspolitiska eller som är jämställda med arbetskraftspolitiska åtgärder (L 1215/2005; Uusikylä m.fl. 2005, 16).

Kommunförbundet r.f. representerar Finlands kommuner och städer och stöder dem i genomförandet av förändringar. Kommunförbundet drar även upp de invandrarpolitiska linjedragningarna för kommunerna. (Kuntaliitto 2004)

Arbets- och näringsministeriet har en central roll i det operativa främjandet av invandrares sysselsättning samt i verkställandet av den arbetsrelaterade invandringen. Ministeriet följer i samråd med Inrikesministeriet arbetskraftsinvandringens volym och struktur (TEM, 2008, 2). Arbets- och näringscentralerna har det regionala ansvaret för invandrings- och integrationsfrågor. De sköter, under Inrikesministeriets ledning, den regionala samordningen av invandrares integration och mottagandet av asylsökande. Vid centralerna planerar, styr och följer man mottagandet av personer som får tillfälligt skydd samt sköter de övriga uppgifter som bestäms särskilt. Man kan vid arbetskrafts- och näringscentralen vid behov, efter överläggning med länsstyrelsen inrätta en kommis- 
sion för invandrarfrågor, med syfte att utveckla och planera integrationen av invandrare, sköta andra invandrarfrågor samt arbeta för etnisk jämlikhet och goda etniska relationer (L 1215/2005).

Arbetskrafts- och näringsbyrån ansvarar, tillsammans med arbetskraftsoch näringscentralen, för att sådan arbetskraftsservice som främjar och stöder invandrares integration ordnas. Byråerna ansvarar även för att undervisning $\mathrm{i}$ läs- och skrivkunnighet och grundläggande utbildning ordnas för invandrare som registrerats som arbetssökande. (L 1215/2005). Arbets- och näringsbyrån fattar beslut om vilka åtgärder som kan jämställas med arbetskraftspolitisk vuxenutbildning. Förutsättningen är att åtgärden måste främja invandrarens integration och förbättra dennes möjligheter att få arbete. Arbetskrafts- och näringsbyrån och kommunen samarbetar vid ordnandet av åtgärder och tjänster som främjar och stöder integration samt informerar om dem. Arbets- och näringsbyrån anvisar, i samarbete med kommunen, invandrare, som på grund av hälsotillstånd eller av annan orsak inte kan delta i arbetskraftspolitiska åtgärder, till kommunens åtgärder och tjänster. (L 1215/2005)

Undervisningsministeriet ansvarar för planeringen och genomförandet av utbildningspolitiken. Undervisningsministeriets uppgift är att utveckla invandrarutbildningen på olika utbildningsnivåer. Utbildningsstyrelsen har en central roll i planeringen och utvecklandet av utbildning för invandrare. Utbildningsstyrelsen utarbetar och godkänner rekommendationer och grunder för läroplaner för utbildning av vuxna invandrare (Utbildningsstyrelsen, 2006; 2007; 2008). Utbildningsstyrelsens uppgift är även att utarbeta examensgrunder där det framgår vilka yrkeskunskaper som krävs för examen, vilka delområden utgör en examen, de olika sätten en viss yrkeskunskap kan bevisas, grunderna för bedömning av avläggande av en examen etc. (Uusikylä m.fl., 2005, 22). På Utbildningsstyrelsen beslutar man även om den behörighet för statliga eller kommunala tjänster eller uppgifter i Finland som följer av en utländsk examen. Utöver beslut om erkännande ger Utbildningsstyrelsen sakkunnigutlåtanden om utländska yrkesinriktade examina. På Utbildningsstyrelsen har man under åren även producerat studiematerial för undervisning i finska och likaså i läs- och skrivfärdighet för vuxna invandrare. 


\subsection{Nationella aspekter}

Tyngdpunkten har flyttats från humanitär invandring till arbetsrelaterad invandring. Invandrarna betraktas inte längre som en specialgrupp med risk att marginaliseras, utan som en arbetskraftpotential. Ett särtecken, kopplad till den starka arbetsmarknadsorienteringen är individualisering. Syftet med den individuella integrationsplanen, som görs efter att invandraren blivit arbetssökande hos arbetskraftsmyndigheterna, är att utgående från kartläggning av den enskilda invandrarens kunskaper och färdigheter, om möjligt kunna skräddarsy en utbildningsväg som leder till anställning på den öppna arbetsmarknaden. Beträffande integration genom vuxenutbildning kan man konstatera att tyngdpunkten flyttats från invandrarvuxenutbildningar till ordinarie vuxenutbildning. Invandrarna förväntas i allt större utsträckning kunna dra nytta av den ordinarie vuxenutbildningen, delvis genom att man inom ramen för den utvecklar särskilda tillvägagångssätt för att kunna integrera invandrarna i ordinarie grupper.

En förutsättning för utnyttjandet av det ordinarie vuxenutbildningssystemet är både nationellt och regionalt välkoordinerade tjänster för vägledning, rådgivning och information. Detta understryks särskilt i de policy- dokument som de senaste två åren utarbetats i samarbete med flera ministerier. Den allmänna strävan efter koordinering inom det finländska vuxenutbildningssystemet omfattar även integrationsutbildningar. Målet är att de skall utgöra en del, en början på ett kontinuum genom vuxenutbildningssystemet till arbetsmarknaden. En ytterligare aspekt av individualisering och integrering på arbetsmarknaden är bättre system och tillvägagångssätt för erkännandet av tidigare examen och validering av tidigare kunskaper och färdigheter.

Gestaltningen av invandrare som grupp är något motsägelsefull. Dels menar man att indelningen av invandrare i (mål)grupper på basen av orsaken till invandring är konstgjord och överflödig, dels förespråkar man åtgärder för att anpassa t.ex. integrationsutbildningen bättre enligt olika målgruppers utgångspunkt och behov, dock inom ramen för den ordinarie (vuxen)utbildningen. Motsägelsefullheten visar kanske på att arbetsmarknadspolitik och utbildningspolitik inte är helt i kongruens med varandra. Det verkar, även i fråga om vuxenutbildning för invandrare, och trots koordineringssträvanden, att kopplingen mellan yrkesinriktad vuxenutbildning (med integration på arbetsmarknaden som mål) och allmänbildande vuxenutbildning (med integration i samhället som mål) blir allt lösare, kanske på grund av en allt starkare betoning på det först- 
nämnda. Det framgår att folkbildningen tilldelas en särskild uppgift i förebyggandet av marginalisering, på lokalt plan och hos givna invandrargrupper (kvinnor, mödrar i stora familjer, icke- läs- och skrivkunniga). Trots att den finländska integrationspolitiken kan beskrivas som arbetslivsorienterad, har utbildningspolitik och (vuxen)utbildning fram till de senaste åren haft en central roll i integrationsfrämjandet. Det sektoröverskridande samarbetet och koordineringen har uppstått främst på grund av förutspådd arbetskratsbrist. En annan orsak till den ökade samverkan och koordineringen är den pågående helhetsförnyelsen av vuxenutbildningen. 



\section{Initiativ till att förstärka integrationen genom vuxenutbildning}

Den grundläggande utbildningen i Finland består av en nioårig enhetsskola, som börjar vid sjuårsålder. Året innan den grundläggande utbildningen börjar har barnet möjlighet att delta förskoleundervisning. Den grundläggande utbildningen är indelad i två nivåer årskurserna 1-6 i och årskurserna 7-9. Det allmänbildande gymnasiet fullgörs på 2-4 år och avslutas med en riksomfattande studentexamen. Examina inom yrkesutbildningen är treåriga (120 studieveckor). Läroavtalsutbildning består av teoretiska studier inom yrkesutbildningen och väglett arbete på en arbetsplats. Den högre utbildningen ges vid yrkeshögskolor med inriktning mot yrkesinriktade expertuppgifter (grundexamina 3 år) och vid universitet (lägre och högre högskole-examina, 3 respektive 5 år).

Vuxenutbildningen består av tre huvudsakliga element. Arbetskraftspolitisk vuxenutbildning syftar till att förbättra tillgången på yrkeskunnig arbetskraft och underlätta de arbetslösas återinträde på arbetsmarknaden. Den ordnas till stor den vid yrkesutbildningscenter för vuxna. I yrkesutbildningen för vuxna används ett system med fristående examina på tre nivåer. Läroanstalterna inom fritt bildningsarbete, med ett stort utbud av intressebaserade vuxenstudier, är medborgar- och arbetsinstitut, folkhögskolor, studiecentraler, sommaruniversitet och idrottsutbildningscentra. 


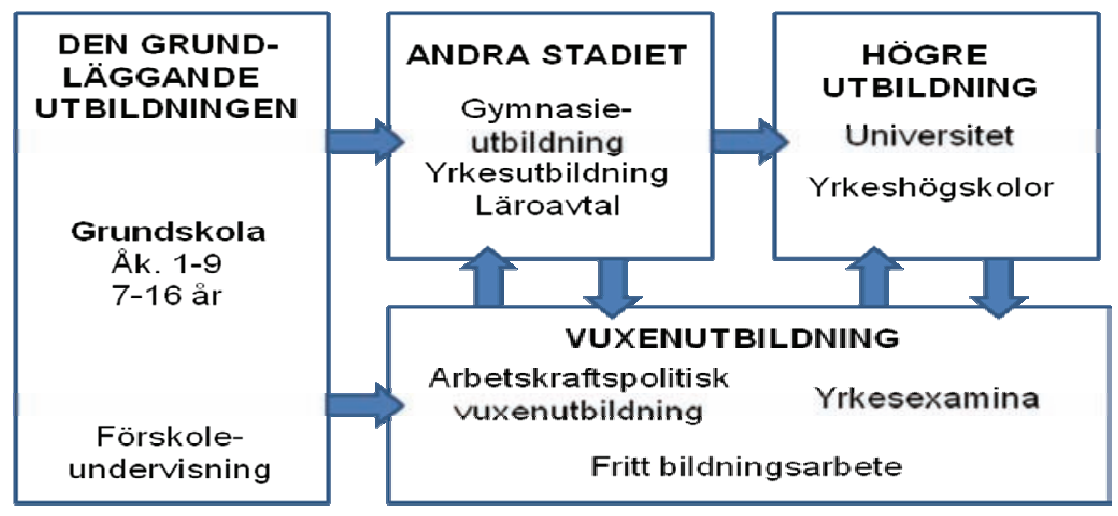

Figur 2. Det finländska utbildningssystemet

\subsection{Systemet för integration och utbildning för vuxna invandrare.}

Den kommun som tagit emot invandraren ansvarar för dennes integration. Efter att blivit bokförd i befolkningsregistret har invandraren rätt till en integrationsplan i tre års tid. Målet är att klarlägga invandrarens kunnande och specialfärdigheter så att denne kan vägledas till arbete eller utbildning. Integrationsplanen görs upp vid den arbets- och näringsbyrån som invandraren anmält sig som arbetslös, eller vid kommunens socialbyrå. Planen skall utarbetas senast när invandraren varit arbetslös eller fått utkomststöd i två månaders tid. Målet är att invandraren inom en månad kan anvisas till en integrationsfrämjande och -stödjande åtgärd. Under den tid som integrationsplanen är i kraft är invandraren berättigad till integrationsstöd (arbetsmarknadsstöd och utkomststöd). Planen skall främja invandrarens förutsättningar för delaktighet $i$ arbetslivet och för vidareutbildning samt verksamhet i det finländska samhället. Integrationsplanen upphör en månad efter att invandraren inlett examensinriktade studier, blivit sysselsatt på heltid eller blivit företagare. Kommunerna och arbetsförvaltningen ansvarar även för integrationsutbildning för de vuxna invandrare som inte är arbetslösa, t.ex. hemmamammor, åldringar, förvärvsarbetande samt övriga som befinner sig utanför arbetslivet (L 1215/2005; Uusikylä m.fl., 2005, 16-19, 22-27). 
Integrationsplanen har tre huvudsakliga syften:

a. att främja och stöda invandrarens möjligheter att lära sig finska eller svenska,

b. att hjälpa invandraren att inhämta sådana kunskaper och färdigheter som behövs i samhället och arbetslivet och

c. att främja invandrares möjligheter att delta i samhällslivet

Integrationsplanen kan inbegripa:

A) för de första någon eller flera av de tre arbetskraftspolitiska integrationsutbild-ningarna. Dessa utbildningar, som härefter i denna rapport benämns integrations-utbildningar, finansieras och administreras av Arbets- och näringslivsmyndigheter på regionalt och lokalt plan. Trots att det operativa ansvaret för dessa vuxenutbild-ningar ligger hos Arbets- och näringslivsmyndigheter är det på Utbildningsstyrelsen (som underlyder Undervisningsministeriet) man utarbetar läroplanerna för dessa utbildningar (Uusikylä m.fl., 2005, 21 - 22). Enligt Utbildningsstyrelsen (2007) lämpar sig integrationsutbildningarna även för vuxna invandrare som inte omfattas av integrationslagen. Integrationsutbildningarna omfattar i medeltal 45 studieveckor (ett års studier).

Den mest förekommande (arbetskraftspolitiska) integrationsutbildningen benämns av arbets- och näringslivsmyndigheter som invandrarutbildning. I denna rapport kommer den för tydlighetens skull benämnas integrationsutbildning. Dess längd är 37-56 studieveckor och den inleds med en kartläggning av invandrarens utgångsnivå och studiefärdigheter. Ifall invandraren saknar kunskaper i läs- och skrivfärdigheter anvisas denne i mån och möjlighet till utbildning av vuxna invandrare som saknar läs- och skrivfärdigheter, som omfattar ett läsår (40 sv). För invandrare som behöver mera språkkunskaper för att kunna inleda en yrkesutbildning ordnas Förberedande utbildning för grundläggande yrkesutbildning för invandrare. Utbildningen omfattar 20 - 40 studieveckor. Den leder inte till examen. Målet är att ge färdigheter till vidare yrkesstudier. Läroplansgrunderna för denna utbildning kan användas både för unga och vuxna invandrare (Utbildningsstyrelsen, 2008).

B) För det andra kan integrationsplanen inbegripa grundstudier och yrkesinriktade studier på alla nivåer inom det ordinarie vuxenutbildningssystemet. Om invandraren söker sig till ordinarie vuxenutbildning används benämningen frivillig utbildning. Den kan av arbetsförvaltningen jämställas med arbetskraftspolitisk integrationsutbildning, och därefter ingå i integrationsplanen. 
Därför benämns den även som jämställd utbildning (Statsrådet, 2008, 27). För att kunna ingå $\mathrm{i}$ integrationsplanen får utbildningen dock inte vara examensinriktad och dess längd överskrida tre år, det vill säga vara längre än integrationsplanen är i kraft. Den jämställda utbildningens popularitet har ökat sedan möjligheten till den utvidgades år 2005 att gälla samtliga utbildningsformer. (Statsrådet, 2008, 29). Jämställandet har sina för- och nackdelar. På orter där invandrarna är för få för en regelrätt integrationsutbildning kan dessa anvisas till ordinarie vuxenutbildningar. Jämställandet tar bättre hänsyn till de individuella behoven. Det är dock svårt att följa upp studierna och integrationsprocessen, på grund av att invandrarna registreras som vanliga vuxenstuderande. Ansvaret över dessa studerande ligger fortsättningsvis hos den arbets- och näringsbyrå som fattat beslutet om jämställandet. (Statsrådet, 2008, 29).

För de högutbildade invandrarnas del handlar åtgärderna om godkännande av examina, avläggande kompletterande studier, språkundervisning (även yrkesspecifik sådan) och kunskaper i det finländska arbetslivet (Statsrådet, 2008, 30). Vid sidan om att få sin examen godkänd bör de högtutbildade invandrarna avlägga allmänna språkexamina för att få sin kommunikativa språkförmåga konstaterad. Examensintyget kan användas vid ansökan om arbets- eller studieplats och för att kunna erhålla finskt medborgarskap. Det fria bildningsarbetet har de senaste åren i större utsträckning engagerat sig i invandrarutbildning och integrering (kurser i finska och svenska samt kurser om den finländska kulturen). Kurserna har oftast varit ekonomiskt betungande för invandrarna, särskilt om de inte ingått i integrationsplanen. Genom så kallade riktlinjesstudier (en särskild vuxenutbild-ningssatsning 2005-2007), i vilka invandrarna var en av målgrupperna, har dessa fått språkutbildning gratis eller för nedsatt pris. (Statsrådet, 2008, 30; Uusikylä m.fl., 2005, 14). I ett aktuellt utvecklingsprogram för fritt bildningsarbete (Opetusministeriö 2009, 77) tilldelas denna vuxenutbildningsform en allt större uppgift i fråga om att svara mot invandrarnas bildningsbehov och stärka förutsättningarna för mångkulturalism.

Figuren nedan är ett försök att sammanfatta fördelningen av ansvar och uppgifter beträffande vuxenutbildning för invandrare i Finland. Det är Arbetsoch näringslivsmyndigheterna som står i centrum, har det operativa ansvaret, åtminstone i ett inledande skede av integrationsprocessen. I regioner och på orter där antalet invandrare är för litet för att man skall kunna ordna särskilda integrationsutbildningar, blir de vuxna invandrarna ofta mer integrerade i de ordinarie vuxenutbildningarna. I och med att även de arbetskraftspolitiska 
integrationsutbildningarna kan, efter anbudsförfarande ordnas av "ordinarie” vuxenutbildningsorganisationer, är överlappningarna många. Till exempel utbildningen för vuxna invandrare som saknar läs- och skrivfärdighet ordnas både som arbetskraftspolitisk utbildning och frivillig (jämställd) utbildning (Utbildningsstyrelsen, 2006, 2007). Det finländska systemet för integration genom vuxenutbildning kan med fog beskrivas som komplex och svår att överblicka. De regionala och lokala variationerna i genomförandet är stora, nationell kvalitetssäkring eller uppföljning till i form av statistik svårligen genomförbar.

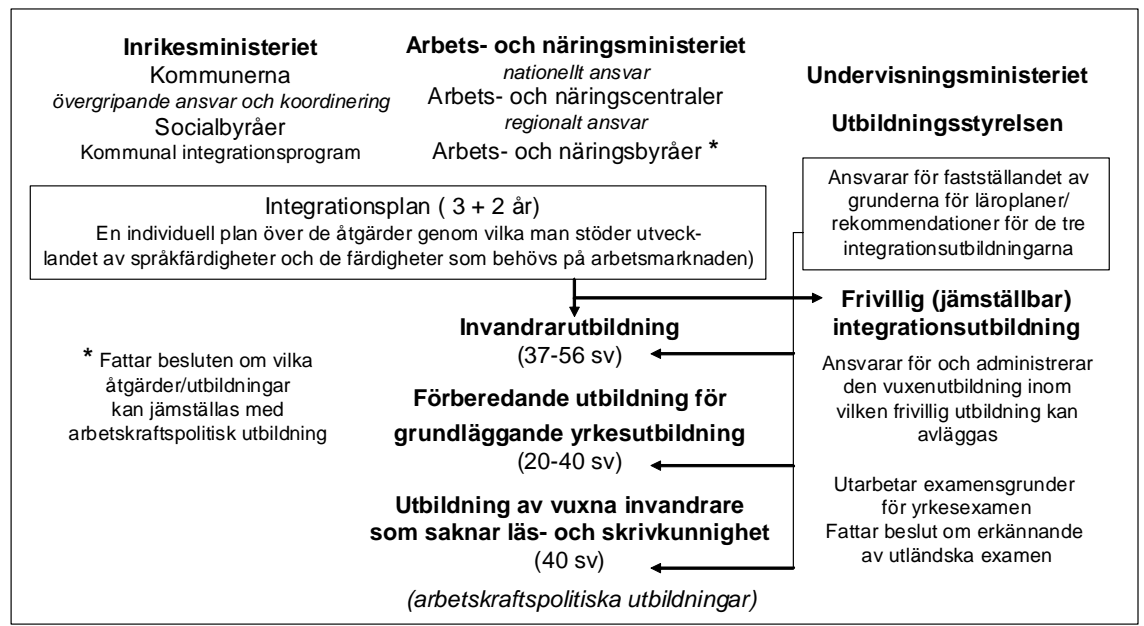

Figur 1. Ansvar och uppgifter i anslutning till integration av vuxna invandrare genom vuxenutbildning

I tabellen nedan framgår hur utbildningsåtgärderna för invandrare utvecklats under 2000-talet. Antalet invandrare som omfattats av integrationsstöd ökade från 2002 till 2008 med 44 \% (från ca. 9000 personer till ca. 13000 personer). Antalet nya integrationsplaner ökade med 39 \% (från ca. 4000 planer till ca. 5300 planer). De arbetsmarknadspolitiska åtgärderna ökade med 63 \%. Då deltagarna i de arbetsmarknadspolitiska utbildningarna ökade från år 2002 till år 2008 med endast 13 \% ökade antalet deltagare i jämställbar utbildning med hela 255 \%. Tyngdpunkten har flyttats från arbetsmarknadspolitisk invandrarutbildning till frivillig integrationsutbildning, med andra ord från integration genom särskilda åtgärder till integration inom ramen för den ordinarie vuxenutbildningen. Deltagare inom den till yrkesutbildning förberedande utbildningen ökade med 32 \%, antalet invandrare i arbetslivspraktik eller -träning 
med 76 \%. Förutom att integrationen sker i allt högre grad inom ordinarie vuxenutbildning har den blivit allt mer arbetslivsorienterad. Ökningen i fråga om anställningar på den öppna arbetsmarknaden var hela $144 \%$. Den positiva utvecklingen har varit följd av högkonjunktur och kraftigt ökad efterfrågan på arbetskraft.

Tabell 2. Utveckling av integrationsutbildningar under 2000-talet (Sisäasiainministeriö 2008, 8; Kotoutumiskoulutus muutoksessa 2007, 10)

\begin{tabular}{lrrrrrrr}
\hline & $\mathbf{2 0 0 2}$ & $\mathbf{2 0 0 3}$ & $\mathbf{2 0 0 4}$ & $\mathbf{2 0 0 5}$ & $\mathbf{2 0 0 6}$ & $\mathbf{2 0 0 7}$ & $\mathbf{2 0 0 8}$ \\
\hline Omfattats av integrationsstöd & 9096 & 10000 & 10445 & 10600 & 10800 & 12000 & 13100 \\
Nya integrationsplaner & $\mathbf{3 8 0 7}$ & $\mathbf{3 0 5 8}$ & $\mathbf{3 0 4 8}$ & $\mathbf{3 5 0 6}$ & $\mathbf{4 2 8 1}$ & $\mathbf{4 9 6 2}$ & 5277 \\
Deltagare i & & & & & & & \\
Arbetsmarknadspolitiska åtgärder & 7152 & 8248 & 8272 & 8912 & 9300 & 10462 & 11662 \\
Arbetsmarknadspolitisk utbildning & 6610 & 6589 & 5785 & 5817 & 6015 & 6630 & 7494 \\
Jämställbar utbildning & 1526 & 2522 & 3571 & 3851 & 4363 & 4925 & 5424 \\
Arbetspraktik eller arbetslivsträning & 1478 & 1743 & 2166 & 2217 & 2322 & 2374 & 2607 \\
Till yrkesutb. förberedande utb. & 887 & 870 & 880 & 996 & 1075 & 1162 & 1175 \\
Anställn. på den öppna & 4046 & 5033 & 5504 & 6363 & 7616 & 8666 & 9865 \\
arb.marknaden & & & & & & & \\
\hline
\end{tabular}

\subsection{De ordinarie integrationsutbildningarna.}

I detta kapitel redogörs för tre integrationsutbildningarna som administreras och finansieras av arbets- och näringslivsmyndigheterna. För invandrare utanför arbetskraften ordnas utbildningarna efter överläggningar mellan arbetsoch näringsbyrån och kommunen. De regionala Arbets- och näringscentralerna köper utbildningarna av läroanstalter enligt principen om anbudsförfarande. Integrationsutbildningarna ordnas främst vid vuxenutbildningscentraler, folkhögskolor samt vid medborgar- och arbetarinstitut (Työministeriö, 2006, 3-12). I samband med att integrationsplanen görs upp får invandraren så kallad integrationshandledning, som pågår under utbildningarna och är en del av den integrationsfrämjande verksamheten. Samtliga tre integrationsutbildningar inleds med individuella kartläggningar i samband med vilka klarlägger bl.a. allmänbildning, inlärningsförmåga, minne samt förmåga att tillägna sig kunskap. Informationen används för att göra upp ett personligt studieprogram. Studieprogrammet bör innehålla åtminstone följande information: 
- bakgrundsfaktorer som inverkar på studierna, t.ex. en bedömning av språkkunskaperna, en bedömning av förutsättningarna för att studera och delta i utbildning, tidigare utbildning och möjligheterna att få utländska studier erkända, tidigare arbetserfarenhet och resultatet av kartläggningen av yrkeskompetensen

- den studerandes planer för utbildning och sysselsättning

- inlärningsmål och centrala innehåll som krävs för att förverkliga planen

- ordnandet av den personliga handledningen och stödet.

Förverkligandet av studieprogrammet utvärderas i samtal mellan utbildaren och den studerande under studiernas gång och när de avslutas. (Utbildningsstyrelsen, 2006, 28, 32). Under integrationsutbildningarna är den studerande berättigad till handledning, som skall utgå från den studerandes behov och mål. Målet är att främja studerandens individuella utveckling, utveckla studiefärdigheten, främja den etniska, könsmässiga och utbildningsmässiga jämlikheten. Handledningen skall bidra till att öka den studerandes välbefinnande, förhindra att studierna avbryts, främja sysselsättningen samt stöda viljan att söka till fortsatt utbildning (Utbildningsstyrelsen, 2008, 30-31).

\subsubsection{Utbildning för vuxna invandrare som saknar läs- och skrivfärdigheter}

Antalet vuxna invandrare som saknar läs- och skrivfärdigheter uppgår till 1 200 - 1300 personer. För dessa ordnas utbildning enligt Utbildningsstyrelsens rekommendation. Rekommendationen är kopplad till den Europeiska kommissionens dokument "Towards a European Qualifications Framework for Lifelong Learning”, i vilket man fastställt åtta grundläggande färdigheter som alla medborgare i ett modernt informationssamhälle bör behärska. Syftet med utbildningen är att invandraren lär sig grunderna i läs- och skrivfärdighet, grunderna i finska eller svenska språket samt får stöd i sin integration. Målet är att invandraren skall lära sig läsa och skriva på antingen svenska eller finska så att denne kan fortsätta studera inom ramen för de övriga integrationsutbildningarna. Språkkunskaperna skall svara mot nivå A1.2 (elementär språkfärdighet stadd i utveckling) enligt Europarådets nivåskala för språkkunskaper. (Utbildningsstyrelsen, 2006, 11; 32)

I undervisningen fokuseras de muntliga språkfärdigheterna, särkilt ord och fraser som kan användas i det vardagliga livet. Målet är att invandraren stärks 
i sin mångkulturella identitet och får en bra grund för en funktionell tvåspråkighet. Därför får invandraren även stöd i att behålla och utveckla sitt eget modersmål. (Utbildningsstyrelsen, 2006, 31, 37). Innan utbildningen inleds görs en kartläggning över invandrarens kunskaper i läsning och skrivning. Den tar minst en vecka i anspråk (35 h) och ger en allmän uppfattning om invandrarens färdigheter i det finska eller svenska språket, kunskaper om det latinska alfabetet, finmotorik samt färdigheter i matematik. (Utbildningsstyrelsen, 2006, 14-15)

\section{Studiernas innehåll}

Enligt rekommendationen skall utbildningen omfatta 200 dagar eller 1400 timmar (200 x 7 timmar), sammanlagt 40 studieveckor. Närstudier omfattar 4-5 timmar per dag, distansundervisning eller handledning 2-3 timmar per dag. Utbildningen borde omfatta ett helt läsår och det är önskvärt att utbildningsanordnaren delar upp utbildningen i två terminer, ytterligare i två moduler som vardera omfattar 700 timmar. På så sätt blir utbildningen mer flexibel, särskilt för invandrare som till exempel av familjeskäl inte har möjlighet att studera regelbundet. Detsamma gäller för invandrare som har behov av att gå en del av utbildningen på nytt eller som vill förflytta sig vidare till en annan utbildning. (Utbildningsstyrelsen, 2006, 5) Enligt rekommendationen skall utbildningen bestå av följande fem studiehelheter:

- finska eller svenska språket

- vardagsfärdigheter och livsbemästring

- samhälls- och kulturkunskap

- arbetslivsfärdigheter

- studiefärdigheter

Finska eller svenska språket. I studierna ingår hörförståelse och tal, läsning och läsförståelse samt skrivning. Målet med hörförståelsen är att den studerande lär sig förstå ett begränsat antal ord, korta meningar, frågor, uppmaningar och förbud, medan målet med talundervisningen är att kunna uttrycka omedelbara behov samt föra en dialog om grundläggande personlig fakta. Övning i muntlig kommunikation fås bland annat genom att göra studiebesök på banken, posten, butiken, apoteket och hälsovårdscentralen. Läsundervisningen har som mål att den studerande lär sig läsning på ord- och satsnivå för att kunna förstå namn, skyltar och andra kortfattade texter. Skrivträningen går 
ut på att lära sig skriva versaler, gemener och enkla huvudsatser samt lära sig sambandet mellan ljud och bokstav.

Vardagsfärdigheter och livsbemästring. Studiehelheten består av sex delhelheter som stöder språkinlärningen och integrationsprocessen. Delhelheterna är 1) att reda sig i vardagen och bekanta sig med sin nya omgivning, 2) handarbete och konstämnen, 3) hushållsfärdigheter, 4) matematik, 5) informationsteknik samt 6) gymnastik och hälsokunskap. Målet med delhelhet ett är att klara av vardagliga situationer och känna till de ställen som erbjuder offentlig service. I delhelhet två är målet att utveckla finmotoriken och handarbetsförmågan. I delhelhet tre är målet att lära de studerande att ta hand om sitt hem. I studierna ingår bl.a. städning, matlagning och användning av el och vatten. Delhelhet fyra har som mål att lära de studerande behärska de elementära räknesätten för t.ex. de dagliga inköpen. I delhelhet fem är målet att lära de studerande att använda datorn och känna till vilka användningsmöjligheter den erbjuder inom studier, arbete och fritid. Den sjätte delhelheten har som mål att få de studerande att förstå levnadsvanornas, kostens och motionens betydelse för välbefinnandet.

I Samhälls- och kulturkunskap är målet att de studerande skall känna till hur det finländska samhället är uppbyggd, hur socialskyddet och hälsovårdssystemet fungerar. De studerande lär känna sina rättigheter och skyldigheter samt de tjänster kommunen, ämbetsverk, myndigheter, polis, butiker, banker och försäkringsbolag erbjuder. Inom kulturkännedom är målet att de studerande lär sig att förhålla sig till värderingar, normer och inställningar i den egna och den finländska kulturen samt utveckla sin förmåga till växelverkan med människor med olika kulturbakgrund. Ett centralt innehåll i studierna är frågor som har betydelse för integreringen i samhället.

Arbetslivsfärdigheter. Målet är att de studerande får bekanta sig med det finländska arbetslivet, i mån och möjlighet under en arbetslivsorienteringsperiod. De studerande förväntas lära sig förstå arbetets betydelse i det finländska samhället; för individens försörjning, för människorelationer för välbefinnandet.

Studiefärdigheter. Målet är att utveckla de studerandes studiefärdigheter och studieteknik. I studierna ingår läsövningar, övningar i att använda tidtabeller och kartor, användning av informationsteknologi och olika informationskanaler och information om vidare studier.

Vid bedömningen tar man fasta på både framstegen och språkfärdigheterna. Feedbacken skall vara uppmuntrande, mångsidig och tillräckligt utförlig. Språkkunskapens olika delområden skall vid bedömas separat. Språkkunska- 
perna bedöms enligt en allmäneuropeisk referensram vilket gör dem jämförbara på riksnivå. (Utbildningsstyrelsen, 2006, 25 - 26)

Erfarenheter av utbildning för vuxna invandrare som saknar läs- och skrivfärdigheter

Määttänen (2007, 14-16) har i sin undersökning intervjuat nio utbildare med erfarenhet av att arrangera utbildning för vuxna invandrare som saknar läs- och skrivfärdigheter. Redan det faktum att utbildningen arrangerades under många olika benämningar (Grunderna i finska språket, Specialutbildning för personer som saknar läs- och skrivfärdigheter, Läs- och skrivkurs samt Finska språkets läroverkstad) vittnar om en heterogenitet i innehåll och genomförande. Längden på utbildningarna liksom längden på dagarna varierade beroende på arrangör. Grupperna bestod oftast av invandrare med många olika nationaliteter, vilket en del av utbildarna såg som en fördel eftersom invandrarna då måste använda sig av finska språket. En del utbildare ansåg det vara lättare att undervisa en grupp med invandrare av samma nationalitet. Risken är då mindre att det uppstår kulturella konflikter. Men denna lösning är inte heller bra eftersom invandrare från samma land börjar kivas, undviker att hjälpa varandra och kan dessutom känna avundsjuka gentemot varandra.

\subsubsection{Integrationsutbildning för vuxna invandrare}

Integrationsutbildning för vuxna invandrare ordnas enligt Utbildningsstyrelsens rekommendation (2007). Rekommendationen lämpar sig för utbildning av vuxna invandrare oberoende av om invandraren omfattas av lagen om invandrares integration och mottagande av asylsökande (493/99, ändrad 118/2002 och 1215/2005) eller inte. Integrationsutbildningens syfte är enligt rekommendationen att:

"ge vuxna invandrare sådana språkliga, samhälleliga och kulturella färdigheter samt livskompetens med hjälp av vilka de kan klara sig i de dagliga livssituationerna i en ny miljö, att delta i arbetslivet och söka sig till fortbildning”.

Utbildningen skall ytterligare ge de studerandena vägledning i hur man skall gå till väga för att få det eventuella yrket eller den examen som skaffats utomlands att uppfylla kraven i det finländska arbetslivet, samt vilken slags tilläggs- eller kompletteringsutbildning som behövs. Vid ansökan till utbildningen iakttas de allmänna urvalsprinciperna för arbetskraftspolitisk utbildning. En invandrare kan även självständigt och på eget initiativ söka sig till utbildningen. 


\section{Studiehelheterna}

Integrationsutbildningen består av studiehelheter vars omfattning kan variera beroende på den studerandes grundutbildning, färdigheter och mål. Även längden på utbildningen varierar enligt vilken utgångsnivå den studerande har när utbildningen börjar. För studeranden som börjar sina studier i svenska eller finska från grunden erbjuds en utbildningshelhet på i medeltal 45 studieveckor (ett års studier). Att lära sig svenska eller finska är en central del av integrationsutbildningen. De övriga studierna är integrerade i språkundervisningen. Enligt Utbildningsstyrelsens rekommendation är avsikten att:

\footnotetext{
"temahelheterna integreras i varandra på ett flexibelt sätt enligt de studerandes behov. Integreringen förväntas framskrida som process som börjar med grunderna i finska eller svenska språket och färdigheterna att klara sig i vardagslivet och framskrider till ett djupare behärskande av språket samt till förståelse av det finländska samhället och den finländska kulturen”.
}

I studiehelheterna ingår handledning, planering och förberedelser för framtida yrkesverksamhet.

Följande sju studiehelheter ingår i integrationsutbildningen:

- en inledande kartläggning

- finska alternativt svenska språket

- färdigheter att klara sig i vardagslivet

- studiefärdigheter

- samhällskunskap och kulturkännedom

- arbetslivsfärdigheter

- valfria studier

Inledande kartläggning används för att klargöra den studerandes utgångsnivå och studiefärdigheter så att denne kan hänvisas till en lämplig utbildningsgrupp. Man utreder läs- och skrivfärdigheter, kunskaper i finska alternativt svenska språket, studiefärdigheter och studieberedskap, studiemotivation och livssituation, tidigare utbildning och arbetserfarenhet samt specialfärdigheter och övriga styrkor. Kartläggningen baserar sig på integrationsplanen och utmynnar i ett individuellt studieprogram.

Finska alternativt svenska språket. I språkstudierna betonas funktionalitet, kommunikation och situationsinriktning; målet är en fungerande språkkunskap med vars hjälp invandraren klarar sig i vardags- och arbetslivet. Man 
betonar vikten av att de studerande blir medvetna om det nära sambandet mellan det finska/svenska språket och de andra studiehelheterna och att de förstår deras betydelse för den sociala och kulturella integrationen. Målet med språkstudierna är att invandraren under utbildningens gång erhåller, antingen i finska eller svenska språket, språkkunskaper motsvarande nivå B1.1 (fungerande grundläggande språkfärdighet) enligt Europarådets nivåskala för språkkunskaper.

Färdigheter att klara sig i vardagslivet. Målet med studiehelheten är att den studerande efter avslutade studier klarar av vardagslivet. Det centrala innehållet i studierna omfattar finländsk matkultur, boende, ekonomi, tidens betydelse (inklusive tidtabeller), hälsa, motion, hygien, offentliga tjänster, trafikkultur, användning av kollektivtrafik samt färdigheter i data- och kommunikationsteknik.

Studiefärdigheter. Målet med studiehelheten är att den studerande känner till det finländska utbildningssystemet och förstår betydelsen av livslångt lärande, samt utvecklar färdigheter i att hantera information från olika källor, lösa problem, identifiera sin egen inlärningsstil och ta ansvar för sitt eget lärande samt söka sig till självstudier eller annan vuxenutbildning.

Samhällskunskap och kulturkännedom. Inom delområdet Samhällets grundläggande struktur och kännedom om landet är målet att den studerande känner till det finländska samhällets struktur och funktion samt förstår betydelsen av demokratin. Inom delområdet Samhällets grundservice är målet att de studerande sätter sig in i Finlands socialskydds- och hälsovårdssystem samt övrig offentlig service. Studier i Kulturell identitet och växelverkan syftar till att den studerande utvecklar förmåga att observera och tolka värderingar, normer och inställningar i den egna och den finländska kulturen.

Studiehelheten Arbetslivsfärdigheter är indelad i tre delområden:

- Arbetskultur och arbetslivskännedom, där målet är att den studerande förstår arbetets betydelse i det finländska samhället.

- Arbetslivsperioden, som skall främja den studerandes möjligheter att få jobb. Under arbetslivsperioden får den studerande praktisk erfarenhet av arbetslivet, utveckling av språkfärdigheterna samt yrkeskunnighet.

- Yrkeskompetens och planering av yrkesbanan har som mål att den studerande får feedback på sin yrkeskunnighet och sina arbetserfarenheter 
Valfria studier erbjuder möjlighet till individualisering. Dessa kan bestå av ledda exkursioner eller perioder på läroanstalter, i företag eller på platser som har anknytning till den studerandes personliga framtidsplan. De valfria studierna kan ordnas på den studerandes modersmål.

Invandrarkvinnor har ofta svårt att delta i hela integrationsutbildningen på grund av vård av barn och familj och behöver därför ofta specialarrangemang för undervisningen. Utbildningsstyrelsen rekommenderar därför utbildningsarrangörerna att använda sig av ett parallellt system i form av integrationsfrämjande verksamhet för invandrarkvinnor några timmar i veckan. Det utbildningsstöd och annat stöd som invandrarorganisationerna eller andra organisationer erbjuder kan för invandrarkvinnorna i en viss livssituation vara ett lämpligare alternativ än heltidsstudier.

Fortsatta studier. Efter integrationsutbildningen kan invandraren antingen fortsätta direkt till en grundläggande yrkesutbildning eller också välja den förberedande utbildningen för grundläggande yrkesutbildning för invandrare. De genomfördra studierna kan efter utbildningsanordnarens gottfinnande tillgodoräknas i den förberedande utbildningen. I Utbildningsstyrelsens rekommendation (2007, 44-45) noterar man ytterligare att de invandrare som anser sig ha förutsättningar för företagande hänvisas till rådgivning för företagare och vid behov till den utbildning för företagare som ordnas som arbetskraftsutbildning. Deltagandet e i utbildningen är en förutsättning för att bli beviljad startpenning.

Erfarenheter av integrationsutbildningen. Suokonautio (2008) har gjort en undersökning om vuxna invandrares erfarenheter av integrationsutbildningen $\mathrm{i}$ Jyväskylä. Under loppet av fem år har 33 invandrares förehavanden följts upp. Stommen i undersökningen utgörs av intervjuer med 11 av invandrarna som fått delge sina erfarenheter av integrationsutbildningen samt komma med förslag till hur den kunde utvecklas. De intervjuade var alla av den åsikten att de hade lyckats förvärva mänskligt kapital i form av språkfärdigheter i finska på ett tillfredställande sätt. Dessa språkfärdigheter var dock inte tillräckliga för att komma in på en yrkesutbildning. Integrationsutbildningen gav inte heller möjligheter till att förvärva kulturellt och socialt kapital. Integrationsutbildningarna konstaterades ske alldeles för ofta i skilda men heterogena undervisningsgrupper, och bestå av icke-sammanhängande utbildningsformer och -åtgärder. 


\subsubsection{Förberedande utbildning för grundläggande yrkesutbildning för invandrare}

Förberedande utbildning för grundläggande yrkesutbildning för invandrare omfattar 20-40 studieveckor. Utbildningsstyrelsen fastställer läroplansgrunderna. Dessa kan användas både för unga och vuxna invandrare vid förberedande yrkesutbildning och vid utbildning som förbereder för läroavtalsutbildning. Den förberedande utbildningen leder inte till examen, men kan ges en branschvis inriktning. Utbildningen är avsedd för invandrare som avser fortsätta med en grundläggande yrkesutbildning och som har sådana basfärdigheter i finska eller svenska som motsvarar den genomsnittliga färdighetsnivån A2.2 (grundläggande språkfärdighet stadd i utveckling) på Europarådets nivåskala för språkkunskaper. (Utbildningsstyrelsen, 2008; Uusikylä, 2005, 25)

Den förberedande utbildningen ordnas för det mesta i yrkesläroanstalter. Efter avslutade studier bör den studerande ha färdighet att avlägga en grundläggande yrkesutbildning som omfattar 120 studieveckor. Den studerande kan, om möjlighet finns, avlägga delar av den grundläggande yrkesutbildningen i samband med den förberedande utbildningen. Studierna räknas sedan till godo i samband med att grundexamen avläggs. (Utbildningsstyrelsen, 2008). Utbildningen kan ingå i invandrarens integrationsplan, och då erhåller invandraren integrationsstöd (Utbildningsstyrelsen 2008, 14).

\section{Studiernas innehåll}

Den förberedande utbildningen kan variera individuellt allt efter den studerandes mål, grundutbildning och utgångsnivå samt den personliga studieplanen. I studierna ingår:

- språkliga färdigheter (10-20 sv)

- matematiska, informationstekniska och naturvetenskapliga färdigheter (3-7 sv)

- samhällskunskap och kulturkännedom (3-7 sv)

- studie- och yrkesvalsfärdigheter (4-12 sv)

- valfria studier (0-4 sv).

Språkliga färdigheter. Målet med språkstudierna är att den studerande kan delta i finskspråkig alternativt svenskspråkig undervisning och känner till den terminologi som behövs vid yrkesinriktade studier och i arbetslivet. I språkstudierna ingår hörförståelse, tal, läsförståelse och skrivning. Den ger även 
färdigheter att själv kunna kommunicera och visa hänsyn till andras åsikter samt uttrycka sig om sådant som berör studierna och det tilltänkta yrket.

I språkstudierna ingår främmande språk, det andra inhemska språket och den studerandes modersmål. Målet är att förstå vikten av mångsidiga språkkunskaper i arbetslivet samt att även i yrkessammanhang värdesätta kunskaper i sitt eget modersmål. Studierna i finska alternativt svenska bedöms med en Ganteckning (godkänd). Samtidigt antecknas den nivå på språkkunskaperna som den studerande uppnått enligt Europarådets nivåskala för språkkunskaper. Målet är att invandraren under den förberedande utbildningen erhåller, antingen i finska eller svenska språket, språkkunskaper motsvarande nivå B1.2 (flytande grundläggande språkfärdighet). Studierna i främmande språk antecknas även med ett $\mathrm{G}$ (godkänd). Prestationerna anses vara godkända då kunskaperna i ett främmande språk når referensnivå A1.3 (fungerande elementär språkfärdighet) på nivåskalan. Den studerandes modersmål bedöms även med ett G, men något kriterium för lägsta godkända prestation fastställs inte.

Matematiska, informationstekniska och naturvetenskapliga färdigheter. Målet med studierna är att den studerande får grundläggande färdigheter i matematik, fysik, kemi och naturvetenskap. De informationstekniska färdigheterna omfattar användning av datorn som stöd i studier. Kunskaperna bedöms enligt en skala nöjaktiga-goda-berömliga.

Målet för Samhällskunskap och kulturkännedom är att den studerande lär sig förstå de finländska förfaringssätten och värdegrunderna, lär sig ta ansvar över sitt liv och sin framtid, lär känna sina rättigheter och skyldigheter, förstår betydelsen av lagstiftning och dess inverkan på samhällets funktion, har en bild av Finlands geografiska läge samt värdesätter sin identitet och använder det mångkulturella som en resurs. Kunskaperna i de centrala innehållen bedöms enligt en skala nöjaktiga-goda-berömliga.

Studie- och yrkesvalsfärdigheter är indelade i fyra delområden; det finländska utbildningssystemet, yrkesval, förberedelse för inlärning i arbetet samt studiefärdigheter. Dessa bedöms med ett G (godkänd) när den studerande känner till det finländska utbildningssystemet, förstår utbildningens betydelse och kan välja en utbildningsväg som är lämplig för honom/henne själv, har färdigheter för fortsatta studier samt har insikter om arbetslivet på en arbetsplats.

Valfria studier. De valfria studierna ordnas utgående från utbudet och de studerades behov. De kan bl.a. bestå av företagsamhet, färdighets- och konstämnen, datorkörkort, hygienpass eller utbildning i arbetarskydd. De valfria 
studierna bedöms antingen med ett G (godkänd) eller också i enlighet med gällande förordning.

Efter avslutade studier erhåller den studerande ett betyg. Även om studierna inte fullföljts så ges ett betyg över de delar som slutförts, samt de studier som den studerande deltagit i utan att få vitsord. I betyget antecknas också ifall den studerande avlagt delar av den grundläggande yrkesutbildningen.

\section{Genomförande}

Omkring 50 läroanstalter har Utbildningsstyrelsens tillstånd att ordna utbildningen. Endast den övergripande omfattningen av utbildningen $i$ antal studieveckor är reglerad genom instruktion, inte t.ex. antalet närstudier per vecka. I en utredning som gjordes år 2006 kom man framtill att antalet närstudier per vecka var igenomsnitt 31 (med en variation 20 - 36h). Antalet deltagare i utbildningen har ökat i jämn takt från 742 deltagare år 2001 till 1175 deltagare år 2008, dvs. med 58 \%. År 2006 deltog 1661 invandrare i den förberedande utbildningen för grundläggande yrkesutbildning, varav 743 slutförde utbildningen. Studieavbrotten har i allmänhet varit klart större än i yrkesinriktad vuxenutbildning i övrigt, orsakerna till studieavbrotten är ofta ekonomiska eller relaterade till familjesituationen. Andelen invandrare över 40 år har varit relativt stor (Opetushallitus, 2009, 81; Sisäasiainministeriö 2008, 25).

Erfarenheter av den till yrkesutbildning förberedande utbildning Utbildningsverket vid Helsingfors stad (Romakkaniemi \& Ruutu, 2001) genomförde år 2001 en kartläggning bland studerande som deltagit i den förberedande utbildningen. Utbildningen motsvarade i stora drag de studerandes önskemål. De upplevde sig ha lärt mera finska och fått kunskaper om olika yrkesbranscher ökade. Enligt lärarna var den främsta fördelen med utbildningen att genom den man fick information om de studerandes kunskaper och färdigheter, vilket gav ett gott underlag att bedöma deras framtida framgångar i examensinriktad utbildning. De största problemen handlade om att i förväg kunna informera om utbildningens innehåll och uppläggning på ett sätt som de studerandena kunde tillgodogöra sig. Ett utfall av informationsutmaningarna var att grupperna blev för heterogena. Även informationsgången mellan olika myndigheter visade sig vara bristfällig. Över hälften (60\%) av de studerande fortsatte inom examensinriktad yrkesutbildning efter den förberedande utbildningen, de flesta inom den teknik, den sociala eller servicebranschen. Omkring $30 \%$ av de studerande avbröt sina studier. De främsta orsakerna till 
studieavbrotten ekonomi, förändringar i livssituationen (t.ex. graviditet), en arbetsplats men framför allt för svaga kunskaper i finska.

\subsubsection{Sammanfattning}

Den övergripande innehållsliga strukturen för de tre integrationsutbildningarna är rätt lik, likaså omfattningen. De centrala innehållsliga elementen är fyra; a) de finska/svenska språket, b) studiefärdigheter, c) vardagslivsfärdigheter och samhällskunskap samt d) arbetslivsfärdigheter. Genom dessa kan man se utbildningarna som förberedelse för fortsatta studier inom det ordinarie vuxenutbildningssystemet och/eller som förberedelse för inträde på arbetsmarknaden. För invandrare som saknar läs- och skrivfärdigheter och/eller har en låg utbildningsnivå, erbjuder de tre på varandra påbyggande utbildningarna $\mathrm{i}$ bästa fall en utbildningsstig, som borde kunna genomföras på tre år (inom ramen för integrationsplanen) och som kunde tänkas ha funktionen av en grundläggande integrationsutbildning. Såsom innehållet och genomförandet är beskriven i läroplanerna kännetecknas denna utbildningsstig av att individualiseringen och valfriheten ökar successivt. Det finns dock inga uppgifter på eller uppföljning av huruvida invandrare följt denna utbildningsstig. Uppföljningen av och forskningen om integrationsplanerna och -utbildningarna, deras innehåll, genomförande och effekter är blygsam, även om behovet av detta uppmärksammats upprepade gånger. Ett system för uppföljning skulle vara av stor vikt för att kunna klarlägga hur antal, innehåll och kostnaderna för integrationsåtgärderna. Ytterligare borde man kunna följa upp behov och innehåll av integrationsåtgärder utgående från olika målgruppers behov (Väänänen m.fl. 2009, 76-77)

\subsubsection{Samlade erfarenheter av integrationsutbildningarna}

Integrationsutbildning för vuxna invandrare finansieras i form av arbetskraftspolitisk utbildning. Invandraren får inget studiestöd, utan erhåller i stället integrationsstöd under tre års tid eller så länge hans/hennes integrationsplan är i kraft. (Työministeriön ohje maahanmuuttajien kotouttamisesta, kotoutumissuunnitelmasta ja kotoutumistuesta, 2006, 12). Under 2008 användes sammanlagt 29,3 miljoner euro för integrerings- och språkutbildning för 16600 invandrare. (Sisäasiainministeriö, 2008, 18). I tabellen nedan framgår att antalet invandrare som genomgått integrationsutbildningar ökade från år 
2005 till år 2007 med cirka 1500 personer (19 \%) samtidigt som andelen arbetslösa 3 månader efter utbildningen minskade med 7 procentenheter. I och med att andelen invandrare som fortsatte i någon annan arbetskraftspolitisk utbildning ökade med 50 \% verkar utbildningens nettoeffekt på sysselsättningen på den öppna arbetsmarknaden vara rätt liten.

Tabell 3. Situationen 3 månader efter utbildningen för de som genomgått arbetsmarknadspolitisk integrationsutbildning (Sisäasiainministeriö 2008, 19).

\begin{tabular}{lccc}
\hline & $\mathbf{2 0 0 5}$ & $\mathbf{2 0 0 6}$ & $\mathbf{2 0 0 7}$ \\
\hline Genomgått utbildning & 7831 & 8162 & 9292 \\
Arbetslösa & 2901 & 2795 & 2781 \\
andel & $37 \%$ & $34 \%$ & $30 \%$ \\
I arb.kraft.pol.utb. & 2355 & 2740 & 3437 \\
andel & $30 \%$ & $34 \%$ & $37 \%$ \\
\hline
\end{tabular}

Lärarnas behörighet inom ramen för integrationsutbildningarna har i en färsk utredning (Utbildningsstyrelsen 2009) klarlagts utgående från det ämnet som dessa i samband med utbildningen främst undervisar i. År 2008 var endast 9 lärare engagerade i utbildning av icke- läs- och skrivkunniga invandrare. Av dessa var 5 lärare (56 \%) behöriga för sin läraruppgift. Antalet lärare engagerade i integrationsutbildning för vuxna var 62, och av dessa var 38 lärare behöriga (61 \%). I den förberedande utbildningen för grundläggande yrkesutbildning för invandrare var antalet lärare 95, och av dessa var 65 (68 \%) lärare behöriga. Av de lärare som undervisade i språk, finska eller svenska, i denna utbildningsform var, $67 \%$ respektive $75 \%$ behöriga. Inom fritt bildningsarbete (främst medborgarinstitut och folkhögskolor), där en betydelsefull del av invandrare avlägger enmed integrationsutbildning jämställbar utbildning, arbetade 86 lärare med invandrare. Av dessa var 64 (74 \%) behöriga.

Genomförandet och effekterna av integrationsutbildningen, den till yrkesutbildningen förberedande utbildningen och den frivilliga (jämställbara) utbildningen utvärderades år 2005 (Uusikylä m.fl. 2005). I utvärderingen konstaterar man att utbildningarna svarat rätt bra mot deltagarnas förväntningar. Särskilt växelverkan mellan lärare och studerande, handledningen, lärarnas kompetens, studiematerialet och organisering av studierna hade uppfattats positivt. Grupperna i dessa utbildningar är dock ofta ytterst heterogena, beträffande såväl studiemotivation och kunnande som de grundläggande språkfärdigheterna. De främsta bristerna gällde individualisering; beaktande av individuella förutsättningar studier, tidigare utbildning och arbetserfarenhet. 
Brister upplevdes även i möjligheterna att påverka innehållet och utformningen av utbildningen, särskilt att ordna stödundervisning för specialgrupper. I utvärderingen noterar man ytterligare att den främsta effekten var ofta att utbildningen ökat deltagarnas vilja att lära sig nya saker. Men i fråga om att utveckla studiefärdigheter, ge underlag för karriärplanering och klargöra livssituationen var effekterna klart sämre. Därmed kan man konstatera att utbildningarnas främsta syfte verkar vara att förstärka beredskapen för fortsatta studier, inte att fungera som en bro in på arbetsmarknaden. Av de som genomgick någon av de tre integrationsutbildningarna år 2003 fortsatte en knappa tredjedel (30 \%) i arbetsmarknadspolitisk utbildning. Lite över en femtedel (17 \%) fick anställning på den öppna arbetsmarknaden och lika stor andel (17 \%) hade fått arbete genom arbetsmarknadspolitiska stödåtgärder. 16 \% befann sig utanför arbetskraften. De förslag utvärderingen utmynnar i är att systemet med integrationsutbildningarna förenklas och strömlinjeformas samt integreras starkare i det övriga utbildningssystemet. Detta förutsätter att myndigheterna förstärker sitt samarbete, t.ex. i fråga om rådgivning och information. De enskilda kommunerna förelås få och ta större och aktivare roll i genomförandet av integrationsprocesserna.

\subsubsection{Vuxna invandrare inom den ordinarie vuxen- och yrkesutbildningen}

De senaste åren har kännetecknats av en intensiv strävan efter att omorganisera den finländska vuxenutbildningen, som är omfattande och heltäckande men fragmenterad och svår att överblicka. För vuxna invandrares del har målet varit att efter integrationsutbildningarna bereda dem möjlighet att delta ordinarie vuxenutbildning, särskilt yrkesutbildning. Här uppstår två utmaningar; för det första är ändamålsenlig val av studieform och -plats beroende av invandrares kapacitet att överblicka och sätta sig in i det fragmenterade systemet. Detta aktualiserar behovet av vägledning och rådgivning för vuxna invandrare. Den andra utmaningen har att göra med det faktum att då invandrare deltar i ordinarie vuxenutbildning statistikförs de som ordinarie vuxenstuderande. Detta omöjliggör uppföljning av genomförande och utfall, därmed utvecklandet av den ordinarie vuxenutbildningen enligt invandrarnas förutsättningar och behov.

\section{Yrkesinriktad grundutbildning och tilläggsutbildning}

Den yrkesinriktade grundutbildningen leder till en yrkesinriktad grundexamen och omfattar 120 studieveckor (3 år). I studierna ingår minst 20 studieveckors 
period av inlärning i arbete, som inkluderar lärdomsprov. Den som saknar avgångsbetyg från en finländsk grundskola kan antas enligt prövning. Ifall den sökande har ett annat modersmål än läroanstaltens undervisningsspråk, kan läroanstalten testa den sökandens kunskaper i undervisningsspråket genom ett språkprov eller en intervju. Invandrare har möjlighet att i stället för studier i modersmål studera svenska eller finska som andraspråk. En del läroanstalter erbjuder även undervisning i det egna modersmålet till studerande med ett främmande modersmål. Vid behov kan invandrare få stödundervisning. Den yrkesinriktade grundutbildningen genomförs vid en läroanstalt eller som läroavtal. Examen kan avläggas på basis av läroplan eller fristående examina. Den yrkeskompetens som examen ger är densamma i vartdera fallet. De studerande kan välja bland mer än 50 olika yrkesinriktade grundexamina inom åtta olika utbildningsområden. Utbildning som leder till grundläggande yrkesutbildning ordnas vid yrkesläroanstalter, yrkesutbildningscenter för vuxna samt folkhögskolor. År 2007 var det totala antalet studerande med annat modersmål än finska inom grundläggande yrkesutbildning 7252 studerande, det vill säga 4,5 $\%$ av samtliga studerande. (Sisäasiainministeriö 2008, 25-26).

\section{Fristående examina}

Systemet med fristående examina utvecklades på 1990-talet för vuxna som saknar examen men har en genom yrkesverksamhet förvärvad yrkesskicklighet. Yrkesskickligheten prövas genom yrkesprov, och den bedöms av både lärare och representanter för arbetslivet. Yrkesprov föregås vanligtvis av så kallad förberedande utbildning. Utbildning som förbereder för fristående examina kan genom finansiering av utbildningsförvaltningen ges som grundläggande utbildning, tilläggsutbildning samt som läroavtalsutbildning. Till systemet hör tre former av examina: yrkesinriktade grundexamina, yrkesexamina samt specialyrkesexamina: Yrkesinriktade grundexamina är till innehållen desamma som avläggs på basis av läroplan (inom läroanstalter), medan grunderna för yrkesexamina och specialyrkesexamina är uppbyggda enligt moduler. För en examen krävs mellan två och 11 olika moduler, beroende på examen. Systemet med fristående examina erbjuder för invandrare goda möjligheter eftersom syftet är att validera de kunskaper och färdigheter som förvärvats utanför utbildningssystemet. Antalet deltagare med annat modersmål än finska, i de för yrkesexamen förberedande utbildningarna, var år 2007 2145 studerande. De flesta av dessa studerande fanns inom två branscher; teknik och kommunikation (35 \% av alla studerande) samt socialvård, hälso- 
vård- och idrott (32 \% av alla studerande). Antal studerande med annat modersmål än finska, som erhöll antingen yrkesexamen eller specialyrkesexamen år 2007 var 2383. Av dessa avlade 40 \% examen inom branschen teknik- och kommunikation och 25 \% inom branschen samhällsvetenskap, företagsekonomi och administration (Sisäasiainministeriö 2008, 27-29).

\section{Läroavtalsutbildning}

Läroavtalsutbildning är en flexibel studieform där teoretiska studier kombineras med praktisk inlärning i arbetet. Studieformen lämpar sig väl för invandrare eftersom undervisningen kan göras mer individuell än inom andra former av yrkesutbildning. Den studerande söker själv upp en arbetsgivare som är villig att göra upp ett arbetsavtal. Därefter anskaffar läroavtalsbyrån den behövliga teoretiska utbildningen. Arbetsgivaren betalar lön enligt kollektivavtal under den tid som den studerande utför den praktiska delen av utbildningen. I samband med de teoretiska studierna kan den studerande få dagpenning, familjebidrag och ersättning för resekostnader samt inkvarteringsersättning om utbildningen ordnas utanför hemorten eller den ort där läroavtalsutbildningen sker. Det finns inga uppgifter om hur stor andel invandrarna utgör av de 43000 studerande (år 2007) inom läroavtalsutbildningen (Sisäasiainministeriö 2008, 31-32).

\section{Arbetskraftspolitisk vuxenutbildning}

Den arbetskraftspolitiska vuxenutbildningen ordnas vid särskilda vuxenutbildningscentra och kan anpassas eller skräddarsys enligt lokalt och regionalt behov av arbetskraft. Utbildningen genomförs i kortare moduler som bygger på varandra. Inom ramen för arbetskraftspolitisk vuxenutbildning har man strävat efter att integrera vuxna invandrare i den ordinarie utbildningen. Särskilt i större städer med större invandrargrupper har man ordnat arbetskraftspolitiska utbildningar specifikt åt invandrare. År 2007 deltog 15600 utlänningar i arbetskraftspolitisk vuxenutbildning, av dessa majoriteten 83 \% i förberedande utbildning och $17 \%$ i yrkesinriktad utbildning. Antalet deltagare i särskilda arbetskraftspolitiska utbildningar för invandrare var år 200720081242 personer. Enligt uppföljningar har de invandrare som deltagit i arbetskratspolitisk utbildning placerat sig bättre på arbetsmarknaden jämfört med finländare. Orsaken är att i fråga om invandrarna har urvalet ofta varit mer ingående (Sisäasiainministeriö 2008, 29-31). 


\section{Språkexamina}

Allmänna språkexamina testar den allmänna kommunikativa språkförmågan. Examina kan avläggas i nio olika språk medan språkexamina för statsförvaltningen bara kan avläggas i finska eller svenska, det vill säga det andra inhemska språket. Det rekommenderas att invandrare deltar i de allmänna språkproven. Enligt den nya medborgarskapslagen skall en utlänning som ansöker om finskt medborgarskap uppvisa ett officiellt intyg över nöjaktiga skriftliga och muntliga kunskaper i finska eller svenska språket. För intyg krävs allmän språkexamen på färdighetsnivå tre (mellannivå) eller språkexamen för statsförvaltningen (nöjaktiga muntliga och skriftliga kunskaper). Allmänna språkexamina är avsedda för vuxna som vill testa sina språkkunskaper oberoende av hur språkfärdigheterna förvärvats. Utbildningsstyrelsen som administrerar och utvecklar språkexamina har fastställt examensgrunderna. Allmänna språkexamina kan i detta nu avläggas i engelska, finska, franska, italienska, ryska, samiska, spanska, svenska och tyska.

Språkfärdigheten indelas i nio nivåer enligt europeisk modell - från en elementär språkfärdighetsnivå till ett nästan fullständigt behärskande av språket - men för själva examen utnyttjas nivåerna $1-6$. Examinanden avgör själv - efter att bekantat sig med den niogradiga språkfärdighetsskalan - på vilken nivå han/hon vill utföra testet. Allmänna språkexamina arrangeras av vuxenläroanstalt och några högskolor. I tabellen nedan framgår antalet avlagda språkexamina de senaste åren. Uppskattningsvis 70 \% av de som avlägger språkexamina är invandrare. Arbets- och näringsministeriet har förbundit sig att erbjuda alla de invandrare som omfattas av integrationslagen möjlighet att avlägga språkexamina. Detta sker oftast efter att integrationsutbildningen på $40 \mathrm{sv}$ avslutats.

Tabell 4. Antal språkexamina i finska år 2002, 2006, 2007 och 2008 (Inrikesministeriet 2008, 12; Kotoutumiskoulutus muutoksessa 2007, 15).

\begin{tabular}{lrrrr}
\hline & $\mathbf{2 0 0 2}$ & $\mathbf{2 0 0 6}$ & $\mathbf{2 0 0 7}$ & $\mathbf{2 0 0 8}$ \\
\hline Grundnivå & 207 & 134 & 134 & 137 \\
Mellannivå & 286 & 3098 & 3383 & 3703 \\
Högre nivå & 17 & 87 & 134 & 117 \\
Totalt & 510 & 3319 & 3651 & 3957 \\
\hline
\end{tabular}

Språkexamina för statsförvaltningen är främst avsedda för offentligt anställda personer som behöver påvisa sina språkkunskaper i det andra inhemska språ- 
ket. Enligt språklagen har varje finsk medborgare rätt att hos myndigheter använda sitt eget språk, antingen då finska eller svenska.

\section{Erkännande av utländska examina}

Med erkännande av utländska examina avses ett beslut om vilken behörighet utländska examina ger för arbetsmarknaden eller fortsatta studier i Finland. Beslut om erkännande ges som professionellt erkännande och/eller som akademiskt erkännande. Ett professionellt erkännande innebär att a) Utbildningsstyrelsen fattar beslut om den tjänstebehörighet som utländska examina ger i Finland, b) myndigheterna inom olika branscher fattar beslut om beviljandet av rätten att utöva ett yrke samt c) arbetsgivarna inom den privata sektorn bedömer själva vid anställande av ny personal vilken kompetens en utländsk examen ger. Ett akademiskt erkännande innebär att högskolorna och övriga läroanstalter fattar beslut om vilken behörighet en utländsk examen ger för fortsatta studier samt tillgodoräknandet av utländska studier som en del av en finländsk examen.

Utbildningsstyrelsen fattar beslut om a) jämställande av nivån på en högskoleexamen med en i Finland avlagd högskoleexamenoch b) behörighet för ett reglerat yrke. Till de reglerade yrkena hör lärare, examina inom det juridiska området, behörighet inom det sociala området samt behörighet inom räddningsväsendet. Tjänster inom stat och kommun (offentliga sektorn) kräver oftast högskoleexamen på en viss nivå. För att kunna ansöka om beslut för erkännande måste studierna vara slutförda. Beslut kan ansökas av en person som utomlands avlagt en högskoleexamen som omfattar minst tre år eller som utomlands vid en högskola avlagt en studieprestation som kan jämställas med en studieprestation som i Finland är ett behörighetsvillkor.

Utbildningsstyrelsen gjorde hösten 2005 en kartläggning bland personer som ansökt om beslut för erkännande av utländska examina mellan åren 1998 och 2004 (Blomqvist, 2007). Över hälften av de svarande hade avlagt sin examen i Ryssland eller forna Sovjetunionen. Därefter kom examina avlagda i Storbritannien, Estland och Tyskland var följande stora grupp. Syftet med kartläggningen var att klargöra vilken effekt beslut om erkännande hade för sysselsättningen, lönen och anseendet. Enligt resultaten hade det haft mest nytta för självförtroendet, men inte större betydelse för möjligheterna till sysselsättning. Resultatet stärker uppfattningen att även om utländska examina erkänns offentligt är förhållningssättet till dem på arbetsplatserna är en annan sak. Mest positiva vad gäller möjligheterna till löneförhöjning och avancemang var de som fått finländsk medborgarskap (31 \% av de svarande). Det här kan förklaras med 
att dessa förhållandevis ofta hade jobb, och att de övriga hade bristande språkkunskaper som försvårar sysselsättnings-möjligheterna. Eftersom utbildningssystemen varierar i olika länder så är behovet av handledning och rådgivning om vilken fortbildning eller tilläggsutbildning som behövs stort. Behov av fortbildning och tilläggsutbildning är individuellt. Enligt erfarenheterna finns det inte inom det finländska utbildningssystemet tillräckliga möjligheter till fortbildning eller behörighetstest, till exempel för invandrare med utländsk lärarexamen.

I december 2000 inleddes ett projekt - Specima - med syfte att skapa nya modeller för kompletterande behörighetsgivande utbildning för högt utbildade invandrare (Huttunen \& Kupari, 2007; Statsrådet, 2008, 38 - 39). Största delen av deltagarna i projektet var invandrare från forna Sovjetunionen. Av de 240 personerna som deltog i projektet inledde 188 personer en utbildning som antingen var förberedande eller gav behörighet för det egna yrket. Resten deltog i andra åtgärder som finansierades av projektet. Projektet avslutades i augusti 2007. I slutrapporten föreslås att ett organ grundas som följer upp de högutbildade invandrarna i Finland.

\section{Sammanfattning}

Ett av målen med den finländska integrationspolitiken, nämligen att i allt större utsträckning integrera utbildningen av de vuxna invandrarna i den ordinarie vuxenutbildningen har lyckats åtminstone delvis. Antalet och andelen invandrare eller personer med annat modersmål än finska/svenska i de olika yrkesutbildningarna har ökat stadigt under 2000-talet. Inom grundläggande yrkesutbildning är invandrarnas andel $4.5 \%$ klart större än deras andel av befolkningen (2,5 \%), inom den för yrkesexamen förberedande utbildningen hela $11 \%$. Även antalet avlagda språkexamina, särskilt på mellannivån som krävs för medborgarskap, har mångdubblats under två tusentalet. Bedömningen av situationen och utvecklingen försvåras dock av det faktum att invandrarna/ personer med annat modersmål än finska/svenska noteras inte i den vuxenutbildningsstatistik som Undervisningsministeriet årlige sammanställer.

De förslag utvärderingen utmynnar i är att systemet med integrationsutbildningarna förenklas och strömlinjeformas samt integreras starkare i det övriga utbildningssystemet. Detta förutsätter att myndigheterna förstärker sitt samarbete , t.ex. i fråga om rådgivning och information. De enskilda kommunerna föreslå få och ta större och aktivare roll i genomförandet av integrationsprocesserna. 


\section{Särskilda satsningar för att utveckla den integrationsfrämjande vuxenutbildningen}

Utvecklandet av vuxenutbildningen för invandrare har varit ytterst splittrad och fragmenterad, och skett främst utanför vuxenutbildningssystemet. Utbildning och sysselsättning har gått starkt hand i hand, ofta har utbildningen stått i sysselsättningens tjänst. Utvecklingsarbetet beträffande läroplansgrunder och rekommendationer för integrationsutbildningarna och språkundervisningen har främst skett på Utbildningsstyrelsen eller genom projekt som finansierats från Utbildningsstyrelsen. Det mesta av utvecklingsarbetet under 2000-talet har skett genom hundratals sinsemellan okoordinerade projekt som finansierats av den Europeiska Socialfonden eller den Europeiska Regionala Utvecklingsfonden.

\subsection{EU-finansierad integrationsfrämjande projektverksamhet}

I en översikt över de EU-finansierade projekt som administrerats av Undervisningsministeriet 2000-2005 framgår att antalet projekt (från grundläggande utbildning till universitetsutbildning) varit drygt 1600 med en total budget på cirka 440 miljoner euro. Yrkesutbildningens andel av dessa projekt var cirka $25 \%$ och vuxenutbildningens cirka $13 \%$. Inga särskilda uppgifter om de projekt som berört invandrare finns att tillgå (Opetusministeriö 2006b). I Arbets- och näringsministeriets databas för programperioden 2000-2006 presenteras 324 projekt som berört invandrare eller invandring, alternativt haft invandrarna som en av sina målgrupper. Budgeten för dessa projekt varierade 
från knappa 100000 euro upp till 1,5 miljon euro. Innehållsligt-tematiskt kan man i dessa projekt identifiera två huvudsakliga inriktningar:

- yrkesinriktad och arbetsmarknadspolitisk vuxenutbildning med inlärning-i-arbete som fokus

- främjande av mångkulturalism eller förebyggande av marginalisering bland invandrarna.

På Inrikesministeriet har man de senaste åren genomfört ett trettiotal mindre projekt. Presentationen nedan är ett försök att ge en grov översikt över syften, arbetssätten och fokuseringarna i de hundratals projekten.

\section{Sysselsättningsfrämjande utbildningsåtgärder}

En övergripande genomgång av lokala och regionala projekt med målet att dels främja sysselsättningen hos invandrare dels tillgodose regional eller lokal behov av arbetskraft resulterar i en översikt och idealmodell, i vilken komponenter från mindre projekt sammanförs i en helhet. Utbildningsåtgärderna består i de flesta fallen av

- en förberedande eller vägledande utbildning för invandrare, som kombineras med

- arbetsförlagd utbildning (anpassad enligt arbetsgivarens eller arbetsplatsens behov) eller inlärning-i-arbete (som utgår från behoven inom en given bransch/utbildning eller den studerande).

Utbildningarna är ofta skräddarsydda såväl tidsmässigt som innehållsligt. De kan föregås eller bestå av uppsökande verksamhet, olika typer av kartläggningar av invandrarens arbetserfarenhet, kompetenser, potentialer och intressen. På basen av dessa kartläggningar strävar man efter att dels ge en personlig vägledning och rådgivning, dels att utarbeta personliga studie- eller sysselsättningsplaner. Utbildningsaktiviteterna består av att man modifierar existerande integrations-, språk- och IKT-utbildningar och anpassar dessa enligt utgångsläget och de behov som finns på den lokala arbetsmarknaden. I ett flertal av projekten har man strävat efter att utveckla, pröva och sprida metoder och modeller för validering. Likaså ingår produktion av informations- och målgruppsanpassad undervisnings- eller studiematerial som ett viktigt element i många av projekten. 
Majoriteten av projekten handlar om utbildning av eller kompetensutveckling hos olika typer resurspersoner för invandrare. Dessa kan grovt indelas i tre grupper. Den första gruppen betstår av "kulturtolkar", med uppgift att kunna beakta etnisk bakgrund/tillhörighet och försöka överbrygga kulturskillnader samt klara av problem som uppstår på grund av invandares bristfälliga språkkunskaper. Den andra gruppen resurspersoner består ofta av myndigheter som arbetar regelbundet med invandrare. Förutom insikter i multikulturalism är dessa ofta i behov av att utveckla färdigheter i att koordinera olika myndigheters aktiviteter och/eller förmå skapa hållbara kontakter t.ex. mellan utbildning och arbetsliv. Ytterligare behöver dessa kunna informera och vägleda enskilda invandrare eller grupper av invandrare på ett individanpassat men målinriktat sätt. Det handlar om en brobyggande verksamhet som utvidgar den gängse arbetsbilden. Den tredje gruppen består av arbetsplatshandledare (tutorer/mentorer) med erfarenheter av och insikt inom en given bransch, och med beredskap att utgående från identifiering av organisationskultur och klimat främja möjligheterna till integration i en bransch och en specifik arbetsplats. Denna uppgift handlar ofta både om att bereda arbetsgemenskaper i ett meningsfullt bemötande av invandrare och att vägleda invandrare i de arbetsuppgifter och kultur som än kännetecknande för en given arbetsplats och gemenskap. En framgångsrik integration förutsätter ytterligare att de olika resurspersoner verkar aktivt i lokala nätverk och att deras aktiviteter är sinsemellan integrerade.

De olika elementen i de sysselsättningsfrämjande åtgärderna med syfte att svara mot arbetskraftsbehov illustreras i figuren nedan. Förutom att översikten som helhet omfattar ett stort antal utvecklingsprojekt kan den användas för att identifiera och föra fram tyngdpunkter och fokusområden i enskilda mindre projekt. Det finns exempel på projekt inom vilka man utgående från situationen på den lokala arbetsmarknaden använt sig av kompetenskartläggningar som resulterat i personliga sysselsättningsplaner som man vidare strävat efter att främja genom arbetsplatsförlagd utbildning. I dylika fall har regelrätta utbildningsåtgärder kunnat spela en relativt liten roll. 
KOORDINERING AV TJÄNSTER OCH SERVICE

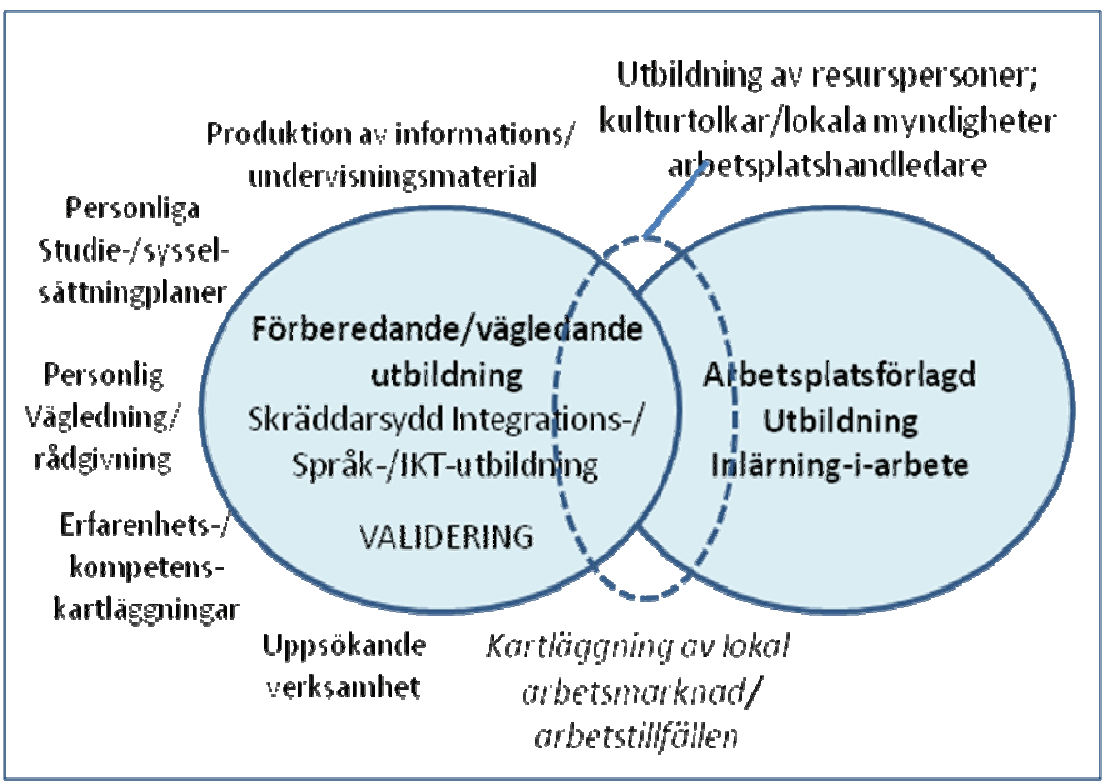

Figur 3. En översikt över integrationsfrämjande utbildningsåtgärder

Beträffande språkundervisningen har målet varit att utveckla de praktiska språk- och kommunikationsfärdigheterna, samt fokusera på branschspecifikt språkbruk. Språkundervisningen har varit arbetslivsförankrad och för undervisningsmetodernas del har man betonat funktionell språkundervisning. I vissa fall har språkundervisningen kombinerats med arbetsplatsförlagd utbildning, vilket har gett möjlighet behandla praktiska språkutmaningar i arbetet och på arbetsplatsen i den undervisningen som pågått i anslutning till den förberedande eller vägledande utbildningen.

\section{Rekryteringsrelaterade och -främjande utbildningsåtgärder}

De rekryteringsrelaterade utbildningsåtgärderna, ofta med syfte att främja arbetsrelaterad invandring har kunnat handla om information, vägledning, inledande kompetenskartläggningar och till och med introducerande utbildningar redan i det land i vilken rekryteringen av arbetskraft har skett. Efter att en grupp (t.ex. läkare, metallarbetare, sjukskötare) anlänt till Finland eller identifierats och sammanförts till en grupp i Finland har man för denna grupp skräddarsytt utbildningshelheter av varierande längd och karaktär. Utbildningarna som utgått från olika typer av erfarenhets- och kompetenskartlägg- 
ningar har kunna bestå av anpassad integrationsutbildning (med tyngdpunkt på integration i samhället), språkundervisning med betoning på fackspråk, arbetslivsorientering, yrkesmässig fortbildning samt handledning och mentorskap på arbetsplatsen. I de arbetsgemenskap och bland de myndigheter som i anslutning till rekryterings- och integreringsåtgärderna blivit engagerade har man genom utbildning och vägledning strävat efter att höja beredskapen att bemöta invandrarna samt koordinera och sammanföra aktiviteter och åtgärder av varierande karaktär. I ett flertal fall har integrationsåtgärderna omfattat de rekryterades familjer. Översikten över sysselsättningsfrämjande utbildningsåtgärder gäller till stora delar även för de rekryteringsfrämjande åtgärderna.

\section{Anpassade utbildningsåtgärder för yrkesutbildning och yrkesexamen}

Strävan efter att utgående från kompetenskartläggningar och valideringsåtgärder individualisera utbildning t.ex. genom personliga studieplaner har gällt även ordinarie yrkesutbildning. Språkundervisningen har inriktats mot fackspråk inom en given bransch och man har utbildat mentorer och arbetsplatshandledare med insikter både i kompetenskraven inom en särskild bransch och beredskap att handleda invandrare. Särskilt beträffande yrkesexamen, i vilka yrkesskickligheten skall påvisas och utvärderas genom yrkesprov har man a) utarbetat modeller och metoder som fungerar som introducerande och vägledande för invandrare, b) utarbetat studiematerial som varit anpassad både enligt målgrupp och bransch, c) anpassat språkundervisningen t.ex. genom kortare helheter och d) ordnat särskild utbildning och vägledning för bedömare av yrkesproven, så att dessa på ett meningsfullt sätt kan relatera till och beakta de aspekter i påvisandet av yrkesskickligheten som kan tänkas påverkas av det faktum att examinanden kommer från en annan kultur eller har en annan etnisk bakgrund.

\section{Integration i lokalsamhället}

Det är relativt få projekt som har varit inriktade på och haft som utgångspunkt och mål att verka och fungera inom ramen för del lokala medborgarsamhället. Det finns dock exempel på projekt, ofta med invandrarkvinnor som målgrupp. I dessa projekt har man ofta utgått ifrån och varit inriktade på att utveckla och anpassa språkundervisningen genom att göra undervisnings- och studiemetoderna mer mångsidiga och målgruppsanpassade (t.ex. genom att utveckla mångsidiga metoder för språktest, kartlägga problem språkinlärning, utarbeta nätbaserad språkinlärningsmaterial). Språkundervisningen har i vissa fall 
kombinerats med någonting som man kunde kalla för lokal kulturkännedom och orientering i lokalsamhället. Detta har inneburit att man involverat och engagerat aktörer inom den tredje sektorn, lokala föreningar m.m. i integrationsprocesserna. I vissa fall ha dessa engagerats med syfte att förebygga marginalisering genom att skapa mötesplatser, sociala verksamhetsmiljöer med låga trösklar för invandrare i särskilda grupper. Aktiviteterna har ytterligare kunnat omfatta introduktion medborgarfärdigheter och de lokala myndigheters service.

\section{Koordinering av service och tjänster}

Vuxenutbildningssystemet består av otaliga utbildningsaktörer på lokal, regional och nationell nivå. I integrationssammanhang och -processer medverkar dessutom ett flertal andra myndigheter. Koordinering av myndigheters tjänster och service både lokalt och nationellt har varit antingen huvudmålet eller ett delmål i ett flertal av projekt. Syftet och målet har för det första varit att sammanföra myndigheter och deras tjänster till i nätverk fungerande helheter och för det andra inom ramen för dessa helheter finna och utveckla välfungerande och hållbara samarbetsmodeller för information, rådgivning och vägledning. I samband med arbetsrelaterad invandring och rekrytering av arbetskraft till givna regioner eller branscher har målet varit att sammanföra myndigheters service och tjänster till så kallade servicekoncept. Tanken har varit att resursstarka invandrargrupper har kapacitet att dra nytta av dessa servicekoncept enligt de mer specifika och individualiserade behoven de har. För resurssvaga grupper (invandrare med låg utbildning eller med risk att marginaliseras) har man utvecklat olika typer informations- och servicepunkter eller -centraler. Här har tanken ofta varit att dessa punkter och -centraler skall för det första vara fysiskt nära, för det andra fungera enligt låga trösklars princip, för det tredje erbjuda information och vägledning på ett heltäckande och samlat sätt och för det fjärde ha tillgång till personal som kan informera och vägleda invandrare med målinriktat utgående från de individuella behoven.

\section{Nätbaserad informations- och studiematerial}

Projekten eller aktiviteterna med syfte att utveckla portaler eller nätbaserad studiematerial för invandrare har varit rätt få. Det finns några portaler, med basinformation om det finländska samhället, kulturen och utbildningssystemet, i vilka information presenteras på ett flertal språk (10-14 olika språk, t.ex. www.infopankki.fi) och/eller på finska på ett lättläst sätt (www.virtuopo.fi). 
Även portalerna med material för utbildare av invandrare är få (http://www.vsy.fi/opinto/ maahanmuuttajat). Självstudiematerial för studier i finska är av varierande karaktär. Dessa är oftast inriktade åt utlänningar i allmänhet, ett flertal av dem till utbytesstuderande vid högskolor och universitet. Utbildningsstyrelsen har utarbetat ett nätbaserat självstudiematerial - Suomea, ole hyvä - specifikt för vuxna invandrare (www.edu.fi/oppimateriaalit/ suomeaolehyva/).

\section{Erfarenheter av integrationsfrämjande utvecklingsarbete i projekt}

Det finns några utvärderingar av de EU-finansierade projekt med invandrare som målgrupp som genomförts under Arbets- och näringsministeriets förvaltningsområde (Lemetyinen \& Riusala 2004; Uusikylä \& Karinen 2005). Ett av syften med utvärderingarna har varit att identifiera så kallade best practices. Erfarenheterna och den samlade bilden av de framgångsrika projekten är rätt entydig. De framgångsrika projekten är entydigt behovs- och efterfrågansbaserade, i förhållande till invandrare som målgrupp och i förhållande till den lokala arbetsmarknaden. Målgrupperna för projekten är klart i förväg definierade och avgränsade. Åtgärderna och aktiviteterna utformas utgående från kartläggningar av invandrarnas kunnande, och anpassas enligt individuella behov. Individuella studie- och vägledningsplaner används systematiskt och följs upp även efter utbildningar och andra åtgärder. Genomförandet av utbildning är anpassad till förutsättningarna och kunnandet t.ex. i mindre och mer homogena invandrargrupper. Ytterligare skräddarsys utbildningarna och åtgärderna utgående från eller i förhållande till lokala arbetsgivares behov. Kontakterna till arbetsgivare skapas redan från början och upprätthålls genom t.ex. studiebesök och praktikperioder. Avslutningsvis behövs ett omfattande stödnätverk, dvs. ett brett engagemang av aktörer inom den offentliga, den privata och den tredje sektorn.

\section{Framtida koordinering av utvecklingsprojekt genom stödstrukturprojekt}

De fragmenterade erfarenheterna av många sinsemellan okoordinerade invandrarprojekten har lett till att man under den pågående programperioden 2007-2013 har valt att genomföra några mera omfattande stödstrukturprojekt. Dessa består av ett nationellt utvecklingsprogram och en samlande stödstruktur för regionala projekt. Inrikesministeriets migrationsavdelning genomför två dylika omfattande stödstrukturprojekt ALPO och MATTO. Syften med dessa är att stärka vägledningen och rådgivningen i det inledande skedet av 
invandringen samt öka resurserna för arbetskraftsinvandring. Inom stödstrukturerna ämnar man förmedla information, ge stöd, erbjuder utbildning och uppmuntra aktörerna inom samarbetsnätverket. Inom stödstrukturen ALPO ( budget 1,4 miljoner euro) är syftet att utveckla en riksomfattande modell för utvecklandet av kompetens för personer som flyttat till Finland samt väglednings- och rådgivningstjänster i invandringens första skede. Man ämnar samla man exempel på best practice och erfarenheter från de regionala utvecklingsprojekten och genom dessa åtgärder stärka olika nätverket av experter. Under år 2009 består utvecklingsprogrammet av 23 pågående projekt.

Stödstrukturen för invandrarprogram MATTO (budget på 2,1 miljoner euro) syftar till att integrera den nationella och internationella dimensionen till en övergripande helhet när det gäller att främja arbetskraftsinvandring. Detta görs genom att man skapar ett nära samarbetsnätverk mellan projekten och de viktigaste aktörerna. Under år 2009 består även utvecklingsprogrammet MATTO av 23 pågående projekt (www.intermin.fi/alpo; hwww.intermin.fi/matto). Målet med utvecklingsprojektet AIKIS, som under åren 2008-2011 administreras av Utbildningsstyrelsen är att skapa ett riksomfattande elektroniskt system för språkutbildning för invandrare. Den är en del av ALPO stödstrukturen för rådgivning och vägledning för invandrare i det inledande skedet. Inom projektet produceras elektroniska verktyg och läromedel för utbildningen i finska eller svenska för invandrare. Man ämnar stöda den arbetsrelaterade invandringen genom att de invandrarna möjligheter att studera finska eller svenska redan i sitt hemland med hjälp av elektroniskt material. AIKIS koordinerar digitaliseringen av proven i allmän språkexamen i finska och svenska på mellannivå. Det kommer att gå snabbare att avlägga språkexamen och bli lättare att delta i proven, eftersom en elektronisk tjänst utvecklas. Verksamhetsplanen för digitalisering av proven förbereds vid Jyväskylä universitet (www.oph.fi/utvecklingsprojekt/aikis).

\subsection{Kultur- och språkutbildning.}

Organisationerna inom fritt bildningsarbete har de senaste åren varit aktiva i utvecklandet av språk- och kulturutbildning för invandrare. Under åren 20052007 skedde utvecklingsarbetet inom ramen för så kallade riktlinjestudier med särskilda projektanslag som beviljades av Utbildningsstyrelsen. Syftet med dessa särskilda studier var att utveckla, testa och befästa arbetsformer och verktyg för på ett mera långsiktigt och systematiskt sätt kunna rekrytera, pla- 
nera och genomföra undervisning i finska och det finländska samhällets kultur utgående från de särskilda förutsättningar och behov som invandrare har. År 2005 deltog sammanlagt cirka 12500 invandrare i sådana riktlinjestudier som var inriktade på språk- och kulturutbildning. Motsvarande siffra år 2007 var cirka 16800 invandrare. Omkring 70 \% av dessa deltog i utbildning eller kurser som ordnades vid de lokala arbetar- och medborgarinstituten. Från och med år 2008 övergick man till ett system med så kallade studiesedel. Systemet med studiesedel ämnar att möjliggöra lägre kursavgifter eller avgiftsfri utbildning/kurser för målgrupper (invandrare, arbetslösa, seniorer och pensionärer, personer med låg utbildning samt personer inlärningssvårigheter) man önskar engagera och för vilka studieavgiften t.ex. på grund av små tillgångar har varit ett hinder för att söka sig till utbildning. En del av stödet kan användas för de kostnader som föranleds av aktivering av målgrupperna, anpassade undervisningsarrangemang samt studiestödjande och ansökningsfrämjande åtgärder. I tabellen nedan framgår antalet projekt och deras finansiering inom ramen för riktlinjestudier (år 2005-2007) och studiesedel (år 2008) vid de olika organisationerna inom fritt bildningsarbete. I jämförelse med de EU-finansierade projekten ovan är projektbidragen mycket små (genomsnitt finansieringen per projekt $11200 €$ ), och dessutom har de totalt sett halverats från år 2005 till år 2008.

Tabell 4. Finansiering av projekt för utvecklandet av språk- och kulturutbildning för invandrare 2005 till 2008 (Opetusministeriö 2008)

\begin{tabular}{lrrrr}
\hline & 2005 & 2006 & 2007 & 2008 \\
\hline Medborgarinstitut & $147000 \mathrm{e}$ & $169400 \mathrm{e}$ & $92800 \mathrm{e}$ & $61000 \mathrm{e}$ \\
& $(16 \mathrm{st})$. & $(25 \mathrm{st})$. & $(11 \mathrm{st})$. & $(8 \mathrm{st})$. \\
Folkhögskolor & $120000 \mathrm{e}$ & $150000 \mathrm{e}$ & $103000 \mathrm{e}$ & $82000 \mathrm{e}$ \\
& $(6 \mathrm{st})$. & $(8 \mathrm{st})$. & $(6 \mathrm{st})$. & $(4 \mathrm{st})$ \\
Sommaruniversitet & $36000 \mathrm{e}$ & $37500 \mathrm{e}$ & $36000 \mathrm{e}$ & $23000 \mathrm{e}$ \\
& $(3 \mathrm{st})$. & $(5 \mathrm{st})$. & $(4 \mathrm{st})$. & $(3 \mathrm{st})$. \\
Studiecentraler & $120500 \mathrm{e}$ & $55000 \mathrm{e}$ & $5000 \mathrm{e}$ & $(3 \mathrm{st})$ \\
& $(6 \mathrm{st})$. & $(4 \mathrm{st})$. & $(1 \mathrm{st})$. & $197000 \mathrm{e}$ \\
Totalt & 423700 & $411900 \mathrm{e}$ & $236800 \mathrm{e}$ & $(18 \mathrm{st})$. \\
& $(31 \mathrm{st})$. & $(42 \mathrm{st})$. & $(22 \mathrm{st})$. &
\end{tabular}




\section{Referencer}

Arajärvi,. P. (2009).

Selvityshanke maahanmuuttajien työllistymisestä ja kannustinloukuista. Helsinki: Sisäasianministeriö; Sisäasiainministeriön julkaisu 2/2009

Blomqvist, C. (2007).

Ulkomailla suoritettujen tutkintojen tunnustaminen. Ingår i Huttunen, H. \& Kupari, T. (red.) Specimasta opittu. Korkeasti koulutetut maahanmuuttajat työelämään. (s. 57-62). Turku: Turun työvoimatoimisto.

Förordning om främjande av

invandrares integration samt mottagande av asylsökande 22.4.1999/511 (ändrad 280/2006).

Hallituksen maahanmuuttopoliittinen ohjelma 2006.

Holm, P., Hopponen, A. \& Lahtinen, M. (2008).

Maahanmuuttajien työkyky 2008. Helsinki: Pellervon taloudellinen tutkimuslaitos. Pellervon taloudellisen tutkimuslaitoksen raportteja nro 210

Huttunen, H. \& Kupari, T. (red.) (2007).

Specimasta opittu. Korkeasti koulutetut maahanmuuttajat työelämään. Turun työvoimatoimisto.

Kuntaliitto. (2004).

Suomen kuntaliiton maahanmuuttopoliittiset linjaukset. Helsinki: Suomen kuntaliitto.

Kotoutumiskoulutus muutoksessa 2007.

Opetus - ja työhallinnon yhteisen työryhmän raportti.

Lagen om främjande av invandrares integration samt mottagande av asylsökande 9.4.1999/493 (ändrad 362/2005, 1215/2005, 1269/2006, 972/2007)

Lemetyinen, T. \& Riusala, K. (2004).

Selvitys maahanmuuttajatyöstä saaduista kokemuksista ja parhaista käytännöistä Pohjanmaalla. Helsinki: Työministeriö. Määttänen, K. (2007).
Luku- ja kirjoitustaidottomien aikuisten maahanmuuttajien koulutukselliset erityistarpeet. Kokemuksia ja hyviä käytänteitä. Jyväskylä: Jyväskylän ammattikorkeakoulu.

Opetushallitus (2009).

Opettajat Suomessa. Lärarna i Finland. Helsinki: Opetushallitus.

Opetusministeriö (2002).

Parlamentaarisen aikuiskoulutustyöryhmän mietintö. Helsinki: Opetusministeriö, Opetusministeriön työryhmien muistioita 3:2002.

Opetusministeriö (2003).

Opetusministeriön maahanmuuttopoliittiset linjaukset. Helsinki: Opetusministeriö, Opetusministeriön työryhmämuistioita ja selvityksiä 2003:7

Opetusministeriö (2006).

Aikuisten perusopetuksen ja lukiokoulutuksen kehittämisohjelmaehdotus vuosiksi 2007-2012. Helsinki: Opetusministeriö. Opetusministeriön työryhmämuistioita ja selvityksiä 2006:33

Opetusministeriö (2006).

Opetusministeriön hallinnonalan rakennerahastohankkeet 2000-2005. Opetusministeriön julkaisuja 2006:40. Helsinki: Opetusministeriö.

Opetusministeriö (2008).

Vapaan sivistystyön kehittämisohjelman väliraportti . Vapaan sivistystyön kehittämisohjelman 2008-2012 valmitseluryhmän väliraportin liiteosa.

Opetusministeriö ja Työministeriö (2007). Työmaa 2008-2012. Työperusteista maahanmuuttoa ja maahanmuuttajaväestön työllistymistä edistävä aikuiskoulutusohjelma. Opetusministeriön ja työministeriön yhteisen virkamiesryhmän ehdotus 16.3.2007

Regeringsprogrammet (2007).

Regeringsprogrammet för statsminister Matti Vanhanens andra regering. Helsingfors: Statsrådet. 
Romakkaniemi, H. \& Ruutu, S. (2001).

Unelma ammatista - kokemuksia maahanmuuttajien valmistavasta koulutuksesta Helsingin ammatillisissa oppilaitoksiss. Helsinki: Helsingin kaupungin opetusvirasto

Sisäasiainministeriö. (2008).

Aikuiskoulutuksen tehtävät maahanmuuttajien työllistymisen edistämisessä. Neljän ministeriön virkamiesryhmän esitykset aikuiskoulutuksen kokonaisuudistuksen johtoryhmälle.

Statsrådet. (2008).

Statsrådets redogörelse till riksdagen för genomförandet av Integrationslagen.

Suokonautio (2008).

Palapelin palat paikoilleen. Maahanmuuttajien kokemuksia kotoutumiskoulutuksesta ja ehdotuksia sen kehittämiseksi. Helsinki: Työ- ja elinkeinoministeriö.

Työministeriö (2006):

Työministeriön ohje maahanmuuttajien kotouttamisesta, kotoutumissuunnitelmasta ja kotoutumistuesta.

Työ- ja elinkeinoministeriö. (2008). Työja elinkeinoministeriön maahanmuuttoasioiden toimintasuunnitelma.

Undervisningsministeriet (2003).

Utbildning och forskning 2003-2008. Utvecklingsplan. Helsingfors: Undervisningsministeriet.

Undervisningsministeriet (2007).

Utbildning och forskning 2007-2012. Utvecklingsplan. Helsingfors: Undervisningsministeriet.

Undervisningsministeriet (2009).

Utvecklingsprogram för fritt bildningsarbete 2009-2012. Slutrapport av undervisningsministeriets beredningsgrupp.

Utbildningsstyrelsen. (2000).

Grunderna för läroplanen och för fristående examen inom den yrkesinriktade grundutbildningen.

Utbildningsstyrelsen. (2006).

Rekommenderad läroplan för utbildningen av vuxna invandrare som saknar läs- och skrivfärdigheter.
Utbildningsstyrelsen. (2007).

Integrationsutbildning för vuxna invandrare. Rekommendation för läroplanen.

Utbildningsstyrelsen. (2008a).

Förberedande utbildning för grundläggande yrkesutbildning för invandrare. Grunder för läroplanen.

Utbildningsstyrelsen (2008b).

Integrationsutbildning för vuxna invandrare. Rekommendation för läroplanen.

Utbildningsstyrelsen (2009).

Lärarna i Finland 2008.

Utbildningsstyrelsen. (2008).

Utbildning för invandrare. (Broschyr)

Uusikylä, P. \& Tuominen, A. \& Mäkinen, A-K. \& Reuter, N. (2005).

Maahanmuuttajien kotoutumiskoulutuksen arviointi. Helsinki: Työministeriö

Uusikylä, P. \& Karinen, R. (2005).

Kohti tuloksellisempaa ja vaikuttavampaa projektitoimintaa. Selvitys ESRrahoitettujen maahanmuuttajahankkeiden onnistumisista ja onnistumisen edellytyksistä. Helsinki: Työministeriö, Tutkimukset ja selvitykset 4/05.

Valtioneuvoston koulutuspoliittinen selonteko eduskunnalle 2006.

Vaherva, T., Malinen, A. Moisio, A. Raivola, R. Salo, P. \& Silvennoinen, H. (2007).

Vapaan sivistystyön vaikuttavuus ja suuntaviivaopinnot. Jyväskylä. Jyväskylän yliopisto, Koulutuksen arviointineuvosto.

Väänänen, A. m.fl. (2009).

Maahanmuuttajien integroituminen suomalaiseen yhteiskuntaan elämän eri osaalueilla. Sektoritutkimuksen neuvottelukunta. Osaaminen, työ ja hyvinvointi. Helsingfors: Työterveyslaitos, Kuntoutussäätiö, Terveyden ja hyvinvoinnin laitos

Webbadresser

www.oph.fi/utvecklingsprojekt/aikis www.intermin.fi/alpo; hwww.intermin.fi/ matto.

www.edu.fi/info/laroavtalsutbildning (hämtad 4.3.2009)

http://www.vsy.fi/opinto/ maahanmuuttajat 
http://www.migri.fi/netcomm/Default.asp? language=SV (hämtad 11.9.2009)

http://www.migri.fi/netcomm/content.asp? article=2374 (hämtad 8.9.2009) 